Chicago-Kent College of Law

Scholarly Commons @ IIT Chicago-Kent College of Law

January 1994

\title{
Constitutionalizing the Economy: German Neo-liberalism, Competition Law and the "New" Europe
}

David J. Gerber

IIT Chicago-Kent College of Law, dgerber@kentlaw.iit.edu

Follow this and additional works at: https://scholarship.kentlaw.iit.edu/fac_schol

Part of the Antitrust and Trade Regulation Commons, Economic Theory Commons, European Law Commons, and the Law and Economics Commons

\section{Recommended Citation}

David J. Gerber, Constitutionalizing the Economy: German Neo-liberalism, Competition Law and the "New" Europe, 42 Am. J. Comp. L. 25 (1994).

Available at: https://scholarship.kentlaw.iit.edu/fac_schol/221

This Article is brought to you for free and open access by the Faculty Scholarship at Scholarly Commons @ IIT Chicago-Kent College of Law. It has been accepted for inclusion in All Faculty Scholarship by an authorized administrator of Scholarly Commons @ IIT Chicago-Kent College of Law. For more information, please contact jwenger@kentlaw.iit.edu, ebarney@kentlaw.iit.edu. 


\section{DAVID J. GERBER}

\section{Constitutionalizing the Economy: German Neo- liberalism, Competition Law and the "New" Europe}

In the years immediately following the end of the Second World War the prospects for economic and political freedom in Europe seemed bleak. Many informed observers saw Europe's future as socialist, predicting a high degree of state control of the economy and a decreasing sphere of operation for personal freedom and economic competition. Yet Western Europe changed direction radically over the next two decades. By the mid-1960s the market economy had regained center stage, and the process of competition had reacquired the respect and allegiance that it had lost decades before.

The primary intellectual impetus for this reversal of direction came not from a traditional liberal bastion such as England, but from a recent enemy of liberalism - Germany. Specifically, it emanated from the small university town of Freiburg in the southwestern corner of Germany. Close to the French and Swiss borders, home to liberal traditions, and far from the centers of German political and economic power, Freiburg provided a haven for a small group of intellectuals who rejected both Nazi totalitarianism and state socialism. The ideas of the so-called "Freiburg School" were the matrix of a new brand of liberal thought that has had an enormous impact on the evolution of social and economic policy in Europe since the war.

Freiburg School thinkers agreed with earlier conceptions of liberalism in considering a competitive economic system to be necessary for a prosperous, free and equitable society. They were convinced, however, that such a society could develop only where the market was imbedded in a "constitutional" framework. This framework was necessary to protect the process of competition from distortion, to assure that the benefits of the market were equitably distributed throughout society and to minimize governmental intervention in the

David J. Gerber is Professor of Law, IIT/Chicago-Kent College of Law. I wish to thank Professors Wolfgang Fikenstscher, Wernhard Möschel, Knut Nörr and Spencer Weber Waller for valuable comments on earlier drafts of this article and Professor Peter Schlectriem and his staff at the University of Freiburg for support and assistance in the research on which it is based. I also gratefully acknowledge financial support from the Marshall D. Ewell Faculty Scholarship Fund of Chicago-Kent College of Law. 
economy. This interpenetration of legal and economic ideas was the essence of the Freiburg School and of the "ordoliberal" school of thought into which it developed. ${ }^{1}$

Despite its enormous importance, ordoliberal thought - and German neo-liberal thought generally - has received little attention in the English-speaking world, and it remains all but unknown in the United States. ${ }^{2}$ Moreover, except in Germany, awareness of these ideas has been confined almost exclusively to economists, while lawyers and political scientists have seldom been exposed to them. Finally, there has been little modern study of the impact of these ideas on the development of European thought.

In this article I address this critically important gap in our understanding of European thought and institutions. I seek to contribute to a fuller understanding of ordoliberal thought, particularly among non-German readers and among lawyers and policy analysts - to whom (together with economists) this body of thought has been addressed. In addition, I sketch the roles these ideas have played in the evolution of German and European legal thought and institutions, in general, and competition law, in particular.

I also offer some thoughts on the potential value of these ideas as guides to current thought. The recent transformations in Europe have dramatically increased the importance of understanding the ordoliberal story. The end of communist domination in the former

1. For discussion of this term, see infra n. 25.

2. In 1983, one leading German commentator noted that "English language material concerning the Freiburg School as a whole has not been found." Wolfgang Fikentscher, II Wirtschaftsrecht 40 n. 59 (1983).

Very few works by members of the Freiburg School have been translated into English. Walter Eucken's principle theoretical work - Grundlagen der Nationalökonomie - was translated into English in 1950 as Foundations of Economics, and his more popular Unser Zeitalter der Misserfolge was translated the following year as This Unsuccessful Age. I have found few references to either of them, and they seem to have had little circulation.

Two collections in translation of seminal articles in the development of thought regarding the German social market economy, including many by members of the Freiburg School, have been published during the last decade. In 1989, the German economist Hans Willgerodt and the British economist and public policy scholar Alan T. Peacock edited an anthology entitled Germany's Social Market Economy: Origins and Evolution [hereinafter Germany's Social Market Economy]. An accompanying volume contains articles on the same topic, primarily by British and German scholars and without participation by American scholars. See German Neo-Liberals and the Social Market Economy (Alan T. Peacock \& Hans Willgerodt eds. 1989) [hereinafter German Neo-Liberals]. The Ludwig-Erhard Stiftung (Foundation) published a similar anthology in 1982, entitled Standard Texts on the Social Market Economy (W. Stützel et al. eds.)[hereinafter Standard Texts].

The only ordoliberal writer to have been extensively translated is Wilhelm Röpke. I am aware of the following translations of his major works: Crises and Cycles (1936), The German Question (1946), Civitas Humana (1948), The Social Crisis of our Time (1950), Welfare, Freedom and Inflation (1957), International Order and Economic Integration (1959), A Humane Economy: The Social Framework of the Free Market (1960) and Economics of the Free Society (1963). 
Soviet Union and the countries of Eastern Europe has led governments there to seek out the paths that Western European countries followed under similar circumstances during the postwar decades. If these countries are to follow the paths there cut, however, they need to understand those paths and to recognize the implications of those ideas. Similarly, the intensifying integration of Western Europe demands awareness of the ideas on which this process was built and of their potential relevance today. At a deeper level, ordoliberal ideas represent a fundamental reinterpretation of the meaning of "liberalism," and as such they deserve consideration in the rekindled debate over that tradition and its future.

\section{Weimar and The Road to Disaster}

German neo-liberal ideas took shape in response to the political and social crises of the Weimar Republic and of Nazi Germany. The failings of the 1920s led from the Weimar Republic to the capture of political power by the Nazis, and neo-liberal thinkers were dedicated to understanding - and avoiding - a recurrence of that fateful process. A brief review of this history thus provides the starting-point for examining German neo-liberal thought. ${ }^{3}$

The Weimar Republic was born after the First World War under a cloud of suspicion and resentment that never lifted. ${ }^{4}$ Many Germans believed that the political leaders associated with the new republic were at least partially to blame for Germany's humiliating military defeat and the concomitant destruction of the Wilhelmine Reich. As a result, few supported Weimar's constitutional democracy, and many actively sought to undermine it. Caught between nationalists and conservatives who resented the imposition of republican government and socialists who rejected the "bourgeois" domination of Weimar institutions, those institutions had little chance of acquiring legitimacy. Hurtling from crisis to crisis, they had few supporters by the end of the 1920s.

This lack of respect for governmental institutions also impaired respect for legal processes. Law increasingly came to be viewed as a tool of power rather than a reliable social institution. Widespread nationalist sympathies on the Bench led to egregious discrimination against socialists in a number of highly-publicized trials, which further undermined confidence in legal institutions. ${ }^{5}$

3. There are many general treatments of the Weimar Republic. See, e.g., Erich Eyck, A History of the Weimar Republic (1962) and, more recently, Detlev Peukert, The Weimar Republic (R. Deveson tr. 1991).

4. The early years of the Weimar period are discussed in David Felix, Walter Rathenau and the Weimar Republic: The Politics of Reparation (1971).

5. For discussion of law and its contexts during the Weimar Republic, see Knut W. Nörr, Zwischen den Mühlsteinen: Eine Privatrechtsgeschichte der Weimarer Republik (1988). 
Economic developments during the Weimar period were similarly chaotic. To the destruction and dislocation of war were added the disruption of socialist experimentation in the immediate postwar period. ${ }^{6}$ Heavy reparation obligations contributed to extraordinary levels of inflation that were not controlled until mid-decade. After some normalization between 1925 and 1928, the economic situation rapidly deteriorated and then collapsed in the worldwide depression that began in $1929 .{ }^{7}$

This political and economic uncertainty profoundly affected the structure of German industry. ${ }^{8}$ As a means of reducing risks, firms turned to cooperative arrangements rather than competition. Cartels grew rapidly in numbers and size, particularly during the last years of the decade, and by the end of the decade most industries were heavily cartelized. 9 Cartels, in turn, became increasingly aggressive in destroying competitors who refused to join them and in using their financial resources to influence government. German neo-liberals regularly recounted the pernicious effects of such cartel behavior.

Weimar's story gained its awful poignancy from its denouement. The instability of the Weimar years led in 1933 to Hitler's takeover. National socialist promises of economic improvement, social solidarity and a return to political stability proved irresistible after almost two decades of turbulence. ${ }^{10}$

\section{The Freiburg School and its Context}

\section{A. The Nazi Period}

In 1933 - just as the Nazis were taking power - one economist (Walter Eucken) ${ }^{11}$ and two lawyers (Franz Böhm ${ }^{12}$ and Hanns Gross-

6. See generally, Werner T. Angress, The Stillborn Revolution: The Communist Bid for Power in Germany: 1921-3 (1963). (1986).

7. See Harold James, The German Slump: Politics and Economics 1924-1936

8. See generally Wehler, "Der Aufstieg des Organisierten Kapitalismus und Interventionstaates in Deutschland," in Organisierter Kapitalismus 36 (Heinrich A. Winkler ed. 1974).

9. For discussion, see, e.g., Hermann Levy, Industrial Germany: A Study of its Monopoly Organizations and their Control by the State (1966). The cartel tradition in Germany can be traced to the so-called "Great Depression" of the 1880 s and 1890s. See generally Hans Rosenberg, Grosse Depression und Bismarckzeit (1967). See also Fritz Kestner, Der Organisationszwang (1912).

10. For the economic aspects of Hitler's road to power, see Henry A. Turner, German Big Business and the Rise of Hitler (1985) and David Abraham, The Collapse of the Weimar Republic (2d ed. 1986)(highly controversial).

11. Walter Eucken had been in Freiburg since 1927, when he was called to a chair in economics at the university. The son of a leading neo-Kantian philosopher (his father was Rudolf Eucken, winner of the Nobel Prize for literature in 1908), Eucken had been focusing on the philosophical foundations of economic thought. See Walter Eucken, Kapitaltheoretische Untersuchungen (1934). For a brief but fascinating portrait of early influences on Eucken's thought, see Jöhr, "Walter Euckens Leben- 
mann-Doerth ${ }^{13}$ ) met in Freiburg and discovered that they had similar readings of the failing of Weimar and similar views of what to do about it. ${ }^{14}$ The fortuitous occurrence that these three were able to work together for a sustained period of time under conditions that were (for the time) exceptionally favorable made possible the genesis of the "Freiburg School."

The interaction of these three scholars seems to have led to spontaneous intellectual combustion. According to Böhm, ". . .each had arrived at a point in his own thinking where the spark was ready to jump (überspringen)."15 They began to work closely together, offering joint seminars, participating in joint scholarly projects and discussing the interplay of their respective ideas. Böhm considered this close association critical to the development of their thought; pointing in particular to the intense cross-fertilization between the disciplines of law and economics.

A common theme soon emerged in their discussions of Germany's plight. ${ }^{16}$ Each had concluded that the lack of an effective, dependable legal framework had led to the economic and political disintegration of Germany. Each believed that the core of the problem had been the inability of the legal system to prevent the creation and misuse of

swerk," 4 Kyklos 257 (1958). See also Francois Bilger, La Pensée Économique Libérale dans L'Allemagne Contemporaine 46.8 (1964).

12. Franz Böhm arrived in Freiburg in 1933 to teach law. From 1925 to 1931 he had worked in the cartel section of the German Ministry of Economics, where he had participated in enforcing the German Cartel Law. See Kronstein, "Franz Böhm," in Festschrift für Franz Böhm zum 70. Geburtstag i, ii (1965). His pioneering study of the ineffectiveness of legal control over cartels was published in 1933. Franz Böhm, Wettbewerb und Monopolkampf: Eine Untersuchung zur Frage des wirtschaftlichen Kampfrechts und zur Frage der rechtlichen Struktur der geltenden Wirtschaftsordnung (1933) [hereinafter Böhm, Wettbewerb und Monopolkampf].

13. Hanns Grossman-Doerth arrived in Freiburg in $\mathbf{1 9 3 3}$ to assume a chair in law. Concentrating on the problems created by private economic power, he had published a major study in 1931 of the use of large corporations and cartels of standard contracts to create their own law and thus avoid societal obligations. Hanns Grossmann-Doerth, Selbstgeschaffenes Recht der Wirtschaft und staatliches Recht (1933).

14. See generally Andreas Heinemann, Die Freiburger Schule und ihre geistigen Wurzeln (1989).

15. Böhm, "Die Forschungs-und Lehrgemeinschaft zwischen Juristen und Volkswirten an der Universität Freiburg in den dreissiger und vierziger Jahren des 20. Jahrhunderts," in Franz Böhm, Reden und Schriften 158, 161 (1960) [hereinafter Böhm, Forschungs-und Lehrgemeinschaft].

16. There were others who shared this basic set of ideas, including, for example, Heinrich Kronstein, a close friend of Franz Böhm and later Professor of Law at Georgetown University Law School, who published a book in 1931 that dealt with the use of subsidiaries by large corporations to avoid legal constraints. See Heinrich Kronstein, Die abhängige juristische Person (1931). According to Wolfgang Fikentscher, this book provided "the starting-point for the neo-liberal way of looking at law." Wolfgang Fikentscher, III Methoden des Rechts in Vergleichender Darstellung 418 (1976). For a discussion of some aspects of Kronstein's life and work, see Gerber, "Heinrich Kronstein and the Development of United States Antitrust Law," in Der Einfluss deutscher Emigranten auf die Rechtsentwicklung in den USA und in Deutschland (Marcus Lutter et al. eds. 1993). 
private economic power. According to Böhm, "The issue on which we focused together was. . the issue of private power in a free society."17

The initiators were soon joined by other, mainly younger, legal and economic scholars who began to make their. own contributions to the central themes being developed by their mentors. By the late 1930 s there was a well-defined group that shared a basic set of insights, objectives and attitudes, and many members of this group played leading roles in propagating these ideas after the war. According to one commentator, "... . what unified all of them was their active temperament, their idealistic philosophy and their unwillingness to witness events with their 'arms crossed." "18

The development of a school of thought espousing views inconsistent with the ideology of a totalitarian regime as powerful and ruthless as that of the Nazis probably could not have occurred in any city in Germany other than Freiburg. Supported by a strong liberal and pluralist tradition in the community and favored by Freiburg's distance from the centers of population and its lack of strategic importance, ${ }^{19}$ the university was able to minimize national socialist influences until almost the end of the war. ${ }^{20}$ Although many members of the Freiburg School were arrested, imprisoned and dismissed from their jobs, local government officials tended to avoid drastic action against them. ${ }^{21}$

17. Böhm, Forschungs-und Lehrgemeinschaft, supra n. 15, at 162.

18. Bilger, supra n. 11, at 76.

19. The special circumstances in Freiburg are reflected in the existence and operation of the so-called "Freiburg Circles" (Freiburger Kreise). These small cells of resistance to Nazism operated with relatively little interference in Freiburg, often drawing resisting intellectuals from other parts of Germany for meetings there. These groups focused on finding a new basis for German society after the war, emphasizing moral and social issues and frequently relying on religious values for support.

Although the Freiburg School of economic and legal thought must be carefully distinguished from these famous resistance groups, Böhm, Eucken and other members of the Freiburg School also belonged to one or more of these circles. See id. at 1554. For discussion, see Christine Blumenberg-Lampe, Das Wirtschaftsprogramm der Freiburger Kreise (1973). Thus the directions and attitudes of the Freiburg School were influenced by these personal contacts, and at the very least the Freiburg scholars found support in the culture of resistance these groups provided.

For the view of an East German scholar that members of the Freiburg School were "not, in principle, opponents of the Nazi regime," see Robert Naumann, Theorie und Praxis des Neoliberalismus 75 (1957). His argument is based on the mere existence of the school and on the unsupported assumption that national socialist officials would not have tolerated their activities if they had been antagonistic to the regime. The claim ignores the special circumstances in Freiburg, the personal tribulations suffered by members of the group and the issue of whether the responsible Nazi officials understood the implications of the school's writings.

20. See generally Constantin von Dietze, Die Universität Freiburg im Dritten Reich, 3 Mitteilungen der List-Gesellschaft 95 (Aug. 9, 1961). Freiburg has been described as "a kind of nature preserve of liberal economic scholarship." Günter Schmölders, Personalistischer Sozialismus 29 (1969). See also Blumenberg-Lampe, id. at 15.

21. According to one commentator, the Freiburg School represented "the quiet, but bitterly fought war of resistance of German economic scholarship." Schmölders, 


\section{B. The Postwar Period: From the Shadows to Center Stage}

With the end of the war, members of the Freiburg School emerged from the shadows in which they had operated for over a decade and quickly found themselves at center stage. Many members of the group soon assumed leadership positions in the reconstruction of Germany. In part, this was because their positions on economic and political issues often comported well with those of the United States occupation authorities, who were convinced that the high levels of cartelization of German industry had contributed to Hitler's political success and to Germany's incentives and ability to wage war. ${ }^{22}$

The U.S. military government sought to develop an economic policy that would both minimize government economic planning and eliminate cartels, and members of the Freiburg School were able to present a coherent plan for achieving these goals. Moreover, they were among the few qualified Germans who were not tainted by ties to nazism, and thus they met the rigorous U.S. denazification standards.

\section{Varieties of Neo-liberalism}

Before looking more closely at ordoliberal ideas, it is important to identify several thinkers and schools of thought that were either included within ordoliberalism or related to it. ${ }^{23}$ In the years following the end of the Second World War there were several groups that could generally be called "neo-liberal,"24 and categorizations of the thinkers and their ideas often vary widely. The Freiburg School was the most influential, however, and other groups either evolved from it or were much influenced by it.

As the isolation of the Freiburg scholars ended after the war, so did the clear identification of their ideas. The term "ordoliberalism" was soon being applied to a somewhat broader stream of thought that featured the basic ideas of the Freiburg School, but also included members who were not directly associated with Freiburg. ${ }^{25}$ In partic-

"Freiburger Imperativ," Frankfurter Allgemeine Zeitung, April 26, 1990 at 15. For discussion of the situation of economists during the Third Reich, see Wernhard Krause, Wirtschaftstheorie unter dem Hakenkreuz: Die bürgerliche Okonomie in Deutschland während der faschistischen Herrschaft (1969).

22. For discussion, see Volker R. Berghahn, The Americanization of West German Industry 1945-1973 at 84-110 (1986).

23. For an overview of German neo-liberalism, see Peacock \& Willgerodt, "Overall View of the German Liberal Movement," in German Neo-Liberals, supra n. 2, at 1.

24. The term "neo-liberal" is not without difficulties. Walter Eucken, for example, did not consider the term applicable to the Freiburg School because it suggested a return to the prior policies of liberalism, whereas he considered ordoliberalism to be something significantly new. See Walter Eucken, Grundsätze der Wirtschaftspolitik 374 (1952) [hereinafter Eucken, Grundsätze].

25. The term "ordoliberal" apparently was first used in Moeller, "Liberalismus," 62 Jahrbücher für Nationalökonomie 214, 224 (1950). The reference is to the "Ordo" or "natural order" of scholastic philosophy, which was used as the title of the famous 
ular, the ideas of Wilhelm Röpke and his followers were often included as part of ordoliberalism. Forced by the Nazis to flee Germany in 1935, Röpke had spent several years teaching in Turkey, before moving to Switzerland, where he taught economics and pursued an active journalistic career. ${ }^{26}$ He was heavily influenced by Walter Eucken and the Freiburg School and shared their basic ideas, but he tended to be less concerned with conceptual and doctrinal sophistication and more with humanistic values.

An even broader categorization that was heavily influenced by the ideas of the Freiburg School was that of the social market economy. The economist Alfred Müller-Armack coined the term (in 1946) and was the writer most closely associated with it, ${ }^{27}$ while Ludwig Erhard, economics minister of the Federal Republic from 1949 through 1964 and its chancellor from 1964 to 1966, was its most famous adherent. Social market economy supporters generally agreed on most points of economic policy with the ordoliberals, but they placed greater emphasis on assuring that the benefits of the market be distributed equitably throughout society. From many perspectives, ordoliberal and social market economy doctrine are very closely related, and the terms are often used almost interchangeably. ${ }^{28}$.

A third direction within neo-liberalism is the classical or "pure" liberalism of Friedrich von Hayek. ${ }^{29}$ Hayek agreed with Eucken about the importance of competition, but, particularly in his later work, he argued that there was no need for the state to play a major role in maintaining the conditions of competition. The market would, he claimed, take care of itself. Although Hayek did not consider himself part of the Freiburg School, he maintained close personal and intellectual ties with it. ${ }^{30}$

ORDO journal that was founded in 1948 by Franz Böhm and Walter Eucken and that became the principal journal of the ordoliberal movement as well as one of the most respected scholarly journals in the German-speaking world relating to economic policy.

26. For discussion of Röpke's thought and activities, see Bilger, supra n. 11, at 93114, and Johnson, "Exiles and Half-Exiles: Wilhelm Röpke, Alexander Rüstow and Walter Eucken," in German Neo-Liberals, supra n. 2, at 40.

27. For discussion, see Reinhard Blum, Soziale Marktwirtschaft: Wirtschaftspolitik zwischen Neoliberalismus und Ordoliberalismus 94 (1969).

28. See id. at 96-128.

29. Hayek was the best-known of the German neo-liberals (he was actually Austrian) in the English-speaking world and particularly in the United States.

30. Hayek knew Eucken well and showed much respect for his thought. In addition, he was a principal contributor for many decades to the $O R D O$ journal. For a comparison of their thinking in this area, see Woll, "Freiheit durch Ordnung: Die gesellschaftspolitische Leitidee im Denken von Walter Eucken und Friedrich A. von Hayek," 40 ORDO 87 (1989). 


\section{Setting the Intellectual Stage}

Ordoliberals focused not only on the institutional and political failures of the Weimar and Nazi periods, but on the intellectual failures implicated in them. They saw contemporary economic and legal thought as fundamentally flawed, and a major part of their agenda was to expose those flaws and thereby avoid them in the future.

According to Walter Eucken, a central problem of economic thought was that it had lost touch with social and political reality. ${ }^{31}$ Adam Smith and other classical economists had recognized that the economy was imbedded in the legal and political system, but during the nineteenth century economic thought had become isolated, and economists had lost sight of both the political and social contexts of economic issues and the influence of law and political institutions on economic phenomena. ${ }^{32}$ One consequence of this isolation was a narrowing of both the liberal tradition and the economic thought so closely associated with it. "Liberal" came to be associated with the idea of "laissez-faire capitalism."

By the 1920s, however, this conception of liberalism had been discredited throughout much of Europe. The social disruptions caused by industrialization, particularly the creation of an industrial proletariat, combined with the disaster of the first World War to identify "liberalism" with economic chaos, political corruption and the exploitation of the working class. In 1926 John M. Keynes had little doubt that this "liberalism" was dead or very close to it. ${ }^{33}$

Rejecting a disfigured liberalism and overwhelmed by the consequences of the First World War, economists and policymakers during the 1920s began to experiment with many varieties of governmental intervention. Governments felt not only justified in intervening in the economy, but obliged by political and economic pressures to do so. Active countercyclical and employment-enhancing intervention seemed an attractive and politically defénsible antidote to the economic chaos of the period. Eucken called this the "age of experimentation," and he did not like it. ${ }^{34}$

In Germany the problem of uncertainty was exacerbated, Freiburg writers claimed, by the dominance of "historicism". ${ }^{35}$ Historicist thought emphasized the futility of deductive economic theorizing,

31. Walter Eucken, Grundlagen der Nationalökonomie 24-37 (9th ed. 1989; 1st ed. 1939) [hereinafter Grundlagen].

32. See generally Ernst-Wolfram Dürr, Ordoliberalismus und Sozialpolitik 27 (1954), also published as Wesen und Ziele des Ordoliberalismus (1954).

33. John M. Keynes, The End of Laissez-Faire? (1926).

34. See Eucken, Grundsätze, supra n. 24, at 55-8.

35. See generally Meyer, "Geschichte und Nationalökonomie: Historische Einbettung und allgemeine Theorien," 40 ORDO 31 (1989). For Franz Böhm, historicism was still a dominant style of thought in economics in the 1930s. Franz Böhm, Die Ordnung der Wirtschaft als geschichtliche Aufgabe und rechtsschöpferische Leistung xi-xviii (1937) [hereinafter Böhm, Ordnung der Wirtschaft]. 
claiming that economic conduct - as conduct in general - could only be understood in its cultural and historical setting. ${ }^{36}$ By the $1870 \mathrm{~s}$, historicism had become the dominant style of economic thought in Germany, and from then until World War I its dominance all but precluded theoretical thought within the German economics profession. ${ }^{37}$

Eucken had himself been trained in the historical school, but by the mid-1920s he had committed himself to "overcoming" historicism. ${ }^{38} \mathrm{He}$ believed that historicism had destroyed the ability of German economists and policymakers to perceive the fundamental principles and necessary components of a market economy. Moreover, the dominance of historicism had tended to isolate German economists from their foreign colleagues. ${ }^{39}$

Eucken agreed that attention had to be paid to economic history and to the particular circumstances within which economic conduct took place, but argued that historical study alone could not lead to an adequate understanding of economic phenomena. Historical analysis had to be interwoven with theory in order to organize and understand economic data. ${ }^{40}$ Historicism's "helplessness" in the face of the economic crises of the Weimar years undoubtedly contributed to Eucken's change of loyalties. ${ }^{41}$ The historical school had provided no answers to the economic chaos of the period, and it seemed unable to offer intellectual tools that could penetrate the frustrating complexity of economic developments.

The inability of economics to supply answers was matched, according to Franz Böhm, by the ineffectiveness of legal thought. Here the culprit was legal positivism. Late 19th century German legal thought had focused on legislation - the words of the statute - as the primary, if not sole, source of law. ${ }^{42}$ This doctrine had originally been seen as a bulwark against discretionary power and as an objective - and, therefore, dependable - framework for social relations.

36. For discussion of the historicist background of ordoliberal thought, see Fritz Holzwarth, Ordnung der Wirtschaft durch Wettbewerb: Entstehung der Ideen der Freiburger Schule 12-29 (1985).

37. "Since [Gustav Schmoller, the leader of the historicist school of economics] had the ear of the Prussian minister of culture, he could assure that no theoretician received a chair [ in economics] in Prussia or even in Germany. If one wanted to study theory in German-speaking territory between 1880 and 1914, one had to go to Austria." Lutz, "Verstehen und Verständigung in der Wirtschaftswissenschaft," in Vorträge und Aufsätze 18 (Walter Eucken Institut ed. 1967).

38. Eucken, "Die Uberwindung des Historismus," 63 Schmollers Jahrbuch 63 (1938) and "Wissenschaft im Stile Schmollers," 52 Weltwirtschaftsarchiv 468 (1940).

39. Although historicism made varying degrees of headway in other European countries, it remained primarily a German phenomenon.

40. For discussion, see infra, text accompanying nn. 62-85.

41. Bilger, supra n. 11 , at 45 .

42. For discussion, see Franz Wieacker, Privatrechtsgeschichte der Neuzeit 458-85 (1967) and Karl Larenz, Methodenlehre der Rechtswissenschaft 36-81 (5th ed. 1983). 
Despite attacks in academic circles and erosion of its strength, ${ }^{43}$ this view of law continued to dominate German legal culture in the 1920s.

As Böhm and his associates saw it, however, legal positivism had quite different consequences in the $1920 \mathrm{~s}$ in Germany. ${ }^{44}$ Because the political system from which legislation emanated merely represented those private interests that were strongest at a particular time, legal positivism was perverted into a tool of those interests. ${ }^{45}$ Under such circumstances, the idea that law was whatever the legislature said it was promoted chaos and injustice rather than legal security. Thus, legal positivism had allowed not only the courts but society in general to lose sight of fundamental values and common objectives, and it had helped pave the way for nazism.

\section{Ordoliberal Goals}

Responding both to economic and political developments and to the perceived failings of legal and economic thought, the ordoliberals sought a new way of thinking about society. They turned to the basic values of liberalism for guidance, but added new elements that transformed the liberal tradition.

A reconstructive imperative dominated the development of ordoliberal thought. Ordoliberal thinkers were concerned not with gradual change within existing institutions, but with laying the foundations for a different kind of society. Many of the central structures of German society had been destroyed or discredited, and the ordoliberals sought to restructure that society. As a result, they tended to think in large terms, to paint their vision of the future with broad strokes, and to seek a new vocabulary of thought.46

The ordoliberal vision of society was defined by rejection of the past and by the search for a "third way" between democracy and socialism, between the American "West" and the Soviet "East." As the economist John M. Clark observed in 1948,

The world is in the grip of a mighty struggle. On one side are forces driving toward chaos and anarchy.... On the other side are forces of centralized control. Between them stand

43. See, e.g., G. Flavius (pseud. for Hermann Kantorowicz), Der Kampf um die Rechtswissenschaft (1906). For a general discussion of the so-called "free law movement" from which much of this criticism stemmed, see Herget \& Wallace, "The German Free Law Movement as the Source of American Legal Realism," 73 Va. L. Rev. 399, 401-19 (1987).

44. See, e.g.., Böhm, Ordnung der Wirtschaft, supra n. 35, at ix-xii. See also Nörr, "From Codification to Constitution: On the Change of Paradigm in German Legal History of the Twentieth Century," 60 Tijdschrift voor Rechtsgeschiedenis 145 (1992).

45. See generally Friedrich Dessauer, Recht, Richtertum und Ministerialbürokratie: Eine Studie über den Einfluss von Machtverschiebungen auf die Gestaltung des Privatrechts (1928).

46. According to Eucken, "the normal discussion of economic policy [is] full of outdated concepts and polarities (Gegensätze)," Eucken, Grundsätze, supra n. 24, at 2. 
the forces and men who are trying desperately to salvage a workable basis for a human and ordered community in which some effective degree of freedom and democracy may be kept alive, without wrecking society by their undisciplined exercise and disruptive excesses. ${ }^{47}$

The ordoliberals were at the center of this conflict.

It is important to recognize that the deepest wellsprings of ordoliberal thought were humanist values rather than efficiency or other purely economic concerns. ${ }^{48}$ Against the backdrop of chaos, devastation and amassed power, the ordoliberals set out to create a tolerant and humane society that would protect human dignity and personal freedom. ${ }^{49}$ Drawing on the central values of classical liberalism, they envisioned a society in which individuals were as free as possible from state interference and in which democratic institutions dispersed political power within society by maximizing participation in public decision-making. Government institutions had the power to eliminate or curb freedoms, and thus the ordoliberals sought to use the legal process to keep that power in check and thereby protect individual freedoms. ${ }^{50}$

The focus of ordoliberal thought was on the role of the economy in society. They accepted the two basic starting points of classical liberalism - that competition is necessary for economic well-being and that economic freedom is an essential concomitant of political freedom. They believed that private rather than governmental decision-making had to direct the flow of economic resources, because this would yield a productive and reliable economic system and simultaneously reduce the power of government. The two effects together would then prevent a repetition of the totalitarian disasters that had befallen Europe.

But the ordoliberals expanded the lens of liberalism. For them, it was not sufficient to protect the individual from the power of government, because governments were not the only threats to individ-

47. John M. Clark, Alternative to Serfdom 6-7 (1948).

48. "Neoliberalism is not to be viewed as a direction in economics or economic policy, but as a humanistically-based intellectual orientation, in which philosophers, socialists, historians, legal and economic scholars have combined, even on the international level." Reinhard Behlke, Der Neoliberalismus und die Gestaltung der Wirtschaftsverfassung in der Bundesrepublik Deutschland 38 (1961).

49. As his student and associate, Leonhard Miksch, wrote of Eucken, "the battle that he waged with his growing group of supporters for a free order for the economy and the society did not emerge from economic theory. It was a battle for the eternal truths of humanity. For him, the economic theory was only a means to develop an "Ordnung" that was to liberate those values from their threatened encirclement (Umklammerung) by chaotic, anarchic, collectivistic and, finally, neo-liberal forces." Miksch, "Walter Eucken," 4 Kyklos 279 (1950). Note Miksch's use of "neo-liberal" here to refer to something separate from, and inimical to, ordoliberalism. Presumably he was here referring to the Hayekian "pure liberal" version of neo-liberalism.

50. See generally Heinemann, supra n. 14, at 81-93. 
ual freedom. Powerful economic institutions could also destroy or limit freedom, especially economic freedom. ${ }^{51}$ Having witnessed the use of private economic power during the Weimar period to destroy political and social institutions, the ordoliberals emphasized the need to protect individuals from misuses of such power. ${ }^{52}$ This meant that the state had to be strong enough to resist the influence of private power groups. In order for government officials to be in a position to create the structures of the new society, the government of which they were a part would have to be able to protect them against private influences.

The Weimar experience led ordoliberals to demand the dispersion of not only political power, but economic power as well. For most, this meant the elimination of monopolies. For others, such as Wilhelm Röpke, the concentration of economic resources was an evil unto itself; they sought an economy composed, to the extent possible, of small and medium-sized firms. ${ }^{53}$ Both groups tended to view economic concentration with suspicion and sought to protect the existence and the economic freedom of small and medium-sized businesses. ${ }^{54}$

Social goals also played a part in this ordoliberal vision of society. "Social security (Sicherheit) and social justice are the greatest concerns of our time," wrote Eucken, ${ }^{55}$ associating himself with an intellectual tradition of "social liberalism" that had developed in the famous Verein für Sozialpolitik before the turn of the century. ${ }^{56}$ Classical liberals had been content to argue that the market, if left to itself, would promote economic growth and thus eventually enhance social welfare, but Eucken and Böhm approached the problem from a different methodological starting point, referring back to the social liberals in situating such justice concerns in a broader context. ${ }^{57}$ For

51. See Eucken, Grundlagen, supra n. 31, at 196-204.

52. See, e.g., Böhm, "Das Problem der privaten Macht. Ein Beitrag zur Monopolfrage," 3 Die Justiz 324 (1928), reprinted in Franz Böhm - Reden und Schriften 25 (Ernst-Joachim Mestmäcker ed. 1960) [hereinafter Böhm, Das Problem der privaten Macht].

53. See, e.g., Wilhelm Röpke, Civitas Humana 80 (1946). According to Reinhard Blum, “The ideal of his [Röpke's] economic policy is a comprehensive Mittelstandspolitik (roughly, small business policy) which should free the market economy from its two weaknesses - monopolies and the proletariat." Blum, supra n. 27, at 76. See also Bilger, supra n. 11, at 101.

54. See, e.g., Bilger, id. at 101.

55. Eucken, Grundsätze, supra n. 24, at 1.

56. See generally, Dieter Lindenlaub, Richtungskämpfe im Verein für Sozialpolitik (1967). Economists in that tradition, notably Lujo Brentano, had sought these goals as well, but in a far less systematic way. See generally James J. Sheehan, The Career of Lujo Brentano: A Study of Liberalism and Social Reform in Imperial Germany (1966).

57. 'For Eucken, 'social' was the equivalent of 'independent,' that is, to live in a world without monopolies and without power." Schlecht, "Macht und Ohnmacht der Ordnungspolitik - Eine Bilanz nach 40 Jahren Sozialer Marktwirtschaft," 40 ORDO 303,9 (1989). 
them, the economy was the primary means for integrating society around democratic and humane principles, but it could perform this role effectively only if it had certain characteristics.58

The market had to function in a way that all members of society perceived as fair and that provided equal opportunities for participation to all. As the decades prior to the war had shown, an economy that made business owners wealthier but was not subject to community rules aimed at assuring fairness could not achieve social support. Böhm and Eucken saw economic power as a major obstacle to social justice, because when private organizations or groups were powerful enough to interfere with the proper functioning of the competitive process, the market would not be perceived as fair and thus could not serve to integrate the community around it. ${ }^{59}$ Eucken was also convinced that it would sometimes be necessary for government to engage in a certain amount of redistribution of income in order to reduce particular hardships within society, although he did not elaborate the standards for such redistribution. ${ }^{60}$

Finally, the image of society that guided the ordoliberals presupposed economic welfare. They relentlessly argued that the only way of achieving sustained economic performance and stability was through an economic order based on competition. ${ }^{61}$ They acknowledged that their political, humanist and social justice claims all rested on the assumption that economic competition would generate economic development - and rapidly. This promise of economic success was critical to the growth of ordoliberal influence. Given the desperate economic situation in postwar Germany, few would have heeded the ordoliberals had they not promised the quick establishment of a sound economy. Although ordoliberal theory is "growthneutral" on its face, under the circumstances of that time the creation of a sound economic system meant economic progress. Moreover, $\mathrm{Eu}-$ cken and most of the ordoliberals were economists, and it was as economists that they were listened to most closely.

\section{Ordoliberal Thought: Foundations and Basic Principles}

The ordoliberal program for achieving these goals centered on a new relationship between law and the economic system. The

58. Böhm claimed that a liberal program could not work if it did not satisfy "social needs." Böhm, Ordnung der Wirtschaft, supra n. 35, at 185.

59. See, e.g., Eucken, Grundsätze, supra n. 24, at 185-93. See also generally Helmut Becker, Die Soziale Frage im Neoliberalismus (1965).

60. See, e.g., Eucken, id. at 319.

61. See, e.g., Röpke, supra n. 53, at 372-5 and Eucken, id. at 350-68. In these contexts the ordoliberals tended to refer not to economic growth, but to "improving economic performance (Leistungssteigerung)." See, e.g., Eucken, id. at 249. From the ordoliberal perspective, a limited amount of income redistribution was not inconsistent with an emphasis on competition, because such redistributions would not distort the competitive structures of the economy. 
ordoliberals believed that economic competition would provide the basis for the society they envisioned, but only where law could create and maintain the conditions under which competition could function properly.

\section{A. Methods and Philosophical Foundations}

An important factor in the success of ordoliberal thought was its depth. Walter Eucken and his associates did not merely argue from existing intellectual paradigms. They developed the epistemological and other philosophical bases necessary to give their policy prescriptions intellectual strength and appeal.62 Referring to his main economic policy work (Grundsätze der Wirtschaftspolitik (Principles of Economic Policy)), Eucken claimed that "More important than all the details in this book is the method - the economic policy thinking that it calls for and from which the formulation and solution of the problems follow." 63 Eucken was proposing a new way of thinking about the organization of economic activity and its relation to society.

\section{The Philosophical Connection}

Called by Friedrich Hayek "the' most serious thinker in the area of social philosophy that Germany had produced in a century,"64 Walter Eucken was the primary architect of the methodological and philosophical framework of ordoliberalism. While it is beyond the scope of this study to explore in detail the influences on Eucken's philosophical thought, two of those influences deserve mention, because of the light they shed on Eucken's thought. ${ }^{65}$ The first was Immanuel Kant. ${ }^{66}$ Eucken refers to Kant in many contexts, but the Kantian theme most central to Eucken's perspective is that "it is the responsibility of the state to find a form in which there is room for sociable coexistence and at the same time the greatest possible opportunity for the free development of individual capacities. The absolute freedom of the natural condition should be constrained by statutes, through which the individual is protected against the discretion of others. But on the other hand the free activity of the many individu-

62. "[The Grundlagen] contained the development of a completely new basis for economic knowledge (eines neuartigen nationalökonomischen Erkenntnisprograms)." Meyer, supra n. 35, at 31 .

63. Eucken, Grundsätze, supra n. 24, at 369.

64. Lenel et al., "Vorwort," 40 ORDO viii (1989). Eucken was widely considered a deep and original thinker. See, e.g., Lenel, "Walter Euckens 'Grundlagen der Nationalökonomie," 40 ORDO 3 (1989) [hereinafter Lenel, Walter Eucken].

65. For general discussion of the intellectual roots of ordoliberalism, see, e.g., Heinemann, supra n. 14, Holzwarth, supra n: 36, and Egon E. Nawroth, Die Sozialund Wirtschaftsphilosophie des Neoliberalismus 21-46 (2d ed. 1962).

66. See Bilger, supra n. 11, at 140. Eucken's use of Kant is, however, quite selective. 
als in competition with each other should advance the community [italics added]."67

A second central influence was that of Edmund Husserl, who is generally considered the father of phenomenology. ${ }^{68}$ Husserl was Eucken's mentor and friend at Freiburg, ${ }^{69}$ and Eucken frequently cites his works on issues of methodology and epistemology. One observer has referred to Eucken's "economic phenomenology,"70 and Eucken's perspectives on economic phenomena clearly reflect Husserl's thought. In particular, Husserl's emphasis on perceiving structures inherent in phenomena is at the core of Eucken's thought. ${ }^{71}$

Husserl's influence is also reflected in Eucken's methodological starting point - the demand for "realism." The conceptualism that had been in vogue for several decades in German academic circles sought to understand reality through logical operations on conceptual categories. This, according to Eucken, made it impossible for them to perceive or comprehend the concrete realities of economic phenomena. ${ }^{72} \mathrm{He}$ demanded that knowledge of such phenomena be rooted in facts rather than in concepts and their logical manipulations. For him, this was the fundamental theoretical challenge. ${ }^{73}$

\section{The Grand Antinomy}

The major obstacle to acquiring reality-based economic and social knowledge was what Eucken called the "great antinomy." In his view, economic knowledge had two fundamental but inconsistent characteristics. It was historical in the sense that all data had a specific temporal locus and could not be fully understood outside that locus. On the other hand, such raw data was accessible to scientific analysis and meaningful interpretation only to the extent that a process of abstraction was employed to relate that data to other data through the use of "general" principles. Viewing economic phenomena exclusively from either an historical or a theoretical perspective, Eucken claimed, necessarily distorted reality. ${ }^{74}$

Yet, said Eucken, that is precisely what had happened in economic thought. Theoretical economists had paid little attention to facts, operating almost exclusively within their own intellectual models. ${ }^{75}$ This tendency was strongest, he believed, in England, which

67. Eucken, Grundsätze, supra n. 24, at 360 .

68. For discussion of Husserl's influence on Eucken, see Holzwarth, supra n. 36, at 89-103.

69. See generally Bilger, supra n. 11, at 47.

70. Id.at 127.

71. See generally Edmund Husserl, 2/1 Logische Untersuchungen 216-93 (5th ed. 1968).

72. Eucken, Grundlagen, supra n. 31, at 27-30.

73. Id. at 21.

74. See generally Lenel, supra n. 64, at 4-7.

75. Eucken, Grundlagen, supra n. 31, at 27-37. 
had been providing much of the leadership in theoretical economics. The historical school that had reigned in Germany had gone to the other extreme, focusing on facts and paying little attention to theory. Both, therefore, were missing the point.

Eucken thus saw the integration of the theoretical-conceptual and historical perspectives as opening a new era in economic thought and policy. He argued that in order to overcome the great antinomy, theory had to be used to perceive patterns in raw historical data and thus organize it and make it meaningful, but that theory had to be derived from, and continuously tested against, observation of historical fact. Many contemporaries felt that Eucken's work in these areas was of enormous significance. ${ }^{76}$

The need to integrate theoretical and historical perspectives led Eucken and his colleagues to call for another form of intellectual integration - of legal and economic knowledge. Since economic phenomena occurred in an institutional and normative context, economic knowledge for Eucken could not be meaningfully dissociated from legal knowledge. The legal system provided the rules for the economic game, and one could not understand economic processes without integrating knowledge of those rules. ${ }^{77}$ But this is what had occurred in Western thought. Economists had considered legal knowledge irrelevant to their enterprise, while legal scholars had failed to recognize the interaction between the legal and economic systems. The result was that neither lawyers nor economists understood the economic-legal phenomena they purported to interpret.

\section{Morphology and Systemic Analysis}

Eucken's response to the need to integrate facts with theory and economic with legal thought was a method he called "thinking in orders (Denken in Ordnungen)." It may have been his most distinctive and important contribution to postwar European thought. ${ }^{78}$ As he put it, "The perception (Erkenntnis) of economic orders (Ordnungen) is the first step in understanding economic reality. ${ }^{79}$ The basic idea was that beneath the complexity of economic data were fundamental ordering patterns (orders) and that only through the recognition of

76. See, e.g., Heuss, “'Grundlagen der Nationalökonomie' vor 50 Jahren und Heute," 40 ORDO 21 (1989) and Bilger, supra n. 11, at 171.

77. See generally Böhm, Ordnung der Wirtschaft, supra n. 35, at 107.

78. See generally Krüsselberg, "Zur Interdependenz von Wirtschaftsordnung und Gesellschaftsordnung: Euckens Plädoyer für ein umfassendes Denken in Ordnungen," 40 ORDO 223 (1989). For some of the intellectual background, see Fikentscher, supra n. 16 , at $416-21$.

79. Eucken, Grundsätze, supra n. 24, at 34 . "We can't say anything sensible about anything that. . .occurs if we are not aware of the Ordnung [involved]." Eucken, Grundlagen, supra n. 31 , at 5. 
these patterns could one penetrate this complexity and understand the dynamics of economic phenomena. ${ }^{80}$

Eucken saw two fundamental "orders." 1 One he called the "transaction economy" (Verkehrswirtschaft), in which economic conduct was organized through private, transactional decision-making. Here private enterprises generated their own plans on the basis of their evaluation of the incentives and disincentives created by economic competition. The second was the centrally administered economy (Zentralverwaltungswirtschaft), in which governmental commands organized economic activity according to criteria external to the economic system. ${ }^{82}$ Popular versions of this distinction became commonplace with the beginning of the cold war, but its contours were far less perceptible before that time. There had long been rather vague talk of differences between capitalism and socialism, but Eucken was the first - at least in Germany, and arguably in all of Europe - to analyze in great detail the systemic characteristics of these two economic orders. ${ }^{83}$

The impact of Eucken's analysis lay in this systemic focus. His "orders" were constructs through which he sought to demonstrate that certain characteristics of economic systems were related to each other systemically - i.e., they fit together such that the density of those characteristics in an actual economic system necessarily increased the capacity of that system to achieve its goals. ${ }^{84}$ For example, private property, the protection of economic freedom and low barriers to entry into markets were individual characteristics of a transaction economy that tended to reinforce each other and thereby increase the effectiveness of the system as a whole.

A corollary to this analysis was that the intermingling of components from these two fundamentally incompatible "orders" in an ac-

80. An intellectual forerunner of ordoliberal thought in this area was the so-called "Marktformenlehre (doctrine of market forms)" that was developed primarily in the $1920 \mathrm{~s}$ and $1930 \mathrm{~s}$ and whose most influential advocate was Heinrich von Stackelberg. See, e.g., Heinrich von Stackelberg, Marktform und Gleichgewicht (1934). For discussion, see Holzwarth, supra n. 36 , at 112-34.

81. See Eucken, Grundlagen, supra n. 31, at 58.

82. For detailed discussion, see Gutmann, "Euckens Ansätze zur Theorie der Zentralverwaltungswirtschaft und die Weiterentwicklung durch Hensel," 40 ORDO 55 (1989).

83. von Mises was one of a few others who had taken preliminary steps in this direction. See Norbert Kloten, "Zur Transformation von Wirtschaftsordnungen," 40 ORDO 99, 104-5 (1989).

84. Eucken's concept of orders has been a source of serious misunderstandings, because some readers have failed to distinguish between "Ordnungen" as conceptual constructs and actual economic systems. As a result, they have accused Eucken and the Freiburg School of being unrealistic. Unfortunately, Eucken does not draw the distinction as consistently as one might wish, but a careful reading of his work reveals that he does not confuse the term "Ordnung" - which he uses to refer to an abstract model - with "Wirtschaftsordnung" - which he sometimes uses to refer to actual economic systems. See Eucken, Grundsätze, supra n. 24, at 372-3. See also generally Lenel, Walter Eucken, supra n. 64, at 8-10, and Kloten, supra n. 83, at 102, 103. 
tual economic system necessarily impaired the functioning of that system. A transaction economy would be harmed, for example, by each instance of governmental intervention, and vice versa! The power of this insight can hardly be imagined from today's perspective, but at the time it had enormous impact. As one observer put it, "Morphology gave liberalism a new foundation." 85 The perception of distinct and mutually incompatible "orders" provided both a new interpretation of the failures of the economy in the interwar period and a new basis for confidence in the market economy. For Eucken, the problems of the twentieth century were a consequence of failing to recognize these orders and their incompatibility. Governmental intervention in the German and other economies in the wake of the First World War had gradually destroyed the market economy, he said, but no one had perceived what was happening.

\section{B. The Competitive Order}

Applying his version of Husserl's analytical method, Eucken and his colleagues distilled the central process of the transaction economy - economic competition. Eucken showed that competition was the essence of such an economy, because it allowed the system to function effectively. Moreover, the higher the level of competition in the economy, the more effectively the system functioned, thus providing the many economic and non-economic benefits the ordoliberals expected of such an economy.

Again, the sharpness of the concept is central to its impact. Eucken's concern was not with competition in loose common usage, but with a specific form of competition, namely, "complete" competition - that is, competition in which no firm in a market has power to coerce other firms in that market. 86 The concept was not new to Eucken, but he gave it a new function. He made it a guide to government policy and developed it as the lodestar of ordoliberal thought. According to Eucken, "The realization of a system of prices according to complete competition is the criterion of every economic (policy) measure." 87

85. Bilger, supra n. 11, at 58.

86. The German term "vollständiger Wettbewerb" generally is translated as "perfect competition," but I here use the term "complete competition" because, as Wernhard Möschel has pointed out, "What counts for him [Eucken] is the absence of coercive power." Möschel, "Competition from an Ordo Point of View," in German Neoliberals, supra n. 2, at $157 \mathrm{n} .16$ This helps recognize the difference in emphasis between the "perfect competition" of neo-classical price theory and ordoliberal thought. For further discussion, see Fikentscher, supra n. 2, at 186-95.

87. Eucken, Grundsätze, supra n. 24, at 254. 


\section{The Concept of an Economic Constitution}

The ordoliberals staked out further new territory by imbedding their analysis of economic phenomena in a political-legal context. ${ }^{88}$ It was here that the interplay of legal and economic thought had its greatest creative force. Relying on legal discourse, the ordoliberals added a "constitutional" dimension to their analysis of economic problems. A community's political constitution and its choices regarding the laws used to implement that constitution, they said, must ultimately establish the characteristics of its economic system. Economic systems did not just "happen"; they were "formed" through political and legal decisionmaking. These fundamental choices determined a nation's "economic constitution (Wirtschaftsverfassung)."

This concept of an economic constitution was the means by which the ordoliberals integrated legal and economic thought. As a perceptive French analyst of the Freiburg School has observed, "With the concept of an economic constitution, the circle had the 'idée-force' that catalyzed all their individual reflections, oriented all their work and made of them a truly new and original school." ${ }^{89}$ The Freiburg School did not invent the term "economic constitution." It had been used during the $1920 \mathrm{~s},{ }^{90}$ generally referring loosely to the basic char-. acteristics of an economic system. During the Weimar period, for example, the relative merits of "capitalist" and "socialist" economic constitutions were discussed. As with other key terms, however, the ordoliberals imbued this one with a new analytical precision and a new interpretive framework.

According to the ordoliberals, and here Franz Böhm's contributions were particularly influential,, 1 an economic constitution is "a comprehensive decision (Gesamtentscheidung) concerning the nature $(A r t)$ and form of the process of socio-economic cooperation." 92 It rep-

88. In this respect ordoliberal thought has parallels in "institutionalist" economic thought. See, e.g., Kloten, supra n. 83, at 404; Vanberg, "Ordnungstheorie' as Constitutional Economics - the German Conception of a 'Social Market Economy', 39 ORDO 17 (1988); and Hutchison, "Institutionalist Economics Old and New," 140 Zeitschrift für die gesamte Staatswissenschaft 20 (1984).

89. Bilger, supra n. 11, at 78-9.

90. The earliest sustained use I have found is in Siegfried Tschierschky, Wirtschaftsverfassung (1924). Its underpinnings derive, however, from the Weimar Constitution. See Knut W. Nörr, Economic Constitution: On the Roots of a Legal Concept (unpublished manuscript). See also Nörr, supra n. 5, at 166-76.

91. For an analysis of Böhm's contributions to ordoliberal thought, particularly in the area of competition law, see Christina Dümchen, Zur Kartellrechtlichen Konzeption Franz Böhms (1980).

92. Böhm, Wettbewerb und Monopolkampf, supra n. 12, at 107. Bohm relied heavily here on ideas developed in the late $1920 \mathrm{~s}$ by Carl Schmitt, a public law theorist who was influential during the Weimar pericd (but who later employed his theoretical talents in the service of the Nazis). Schmitt defined constitution as a "comprehensive decision (Gesamtentscheidung) concerning the nature and form of the political unit." Carl Schmitt, Verfassungslehre 20 (1928). See also Behlke, supra n. 48 , at 48 . 
resents a political decision about the kind of economy a community wants in the same way that the political constitution represents basic decisions about the kind of political system a community wants. According to Böhm, "Only a focus on this idea makes it possible to achieve truly dependable and cogent principles for the interpretation of parts of private and public law. ${ }^{\text {"93 }}$

This concept of an economic constitution intertwined legal and economic perspectives and discourses. It turned the core idea of classical liberalism - that the economy should be divorced from law and politics - on its head by arguing that the characteristics and the effectiveness of the economy depended on its relationship to the political and legal systems. The ordoliberals recognized that fundamental political choices created the basic structures of an economic system.

\section{Ordnungspolitik: The Untranslatable Soul of Ordoliberalism}

The choice of an economic constitution could only be effective, the ordoliberals said, if the legal system were structured to implement that constitutional choice. When a political unit chose a transaction economy in its economic constitution, for example, that choice required the development of governmental policies designed to create and maintain that system. This the ordoliberals called "Ordnungspolitik" (order-based policy),94 and it was the soul of their program.

\section{Implementing the Constitutional Decision}

According to the ordoliberal conception of Ordnungspolitik, individual governmental decisions should both flow from, and be constrained by, the principles embodied in the economic constitution. The economic constitution is to set out a framework of principles and ideals, and governmental policy is to implement these principles and seek to attain these ideals. Where the economic constitution calls for a transaction economy, Ordnungspolitik demands that the legal system be configured so as to create and maintain the conditions of complete competition which would allow that type of economic system to function most effectively. In effect, law is to be used to implement the model of complete competition.

For the ordoliberals, this meant that economic knowledge had to be translated into normative language. In order to establish policy

93. Böhm, Ordnung der Wirtschaft, supra n. 35, at xix.

94. This term is exceptionally difficult to render into English and other languages, because it depends so much on the ordoliberal thinking with which it is associated. The "order" in "order-based policy" is not "order" merely for the sake of any form of ordering, but "order" in the sense of Eucken's economic orders. That referent is not, however', apparent in English translation. As 'Wernhard Möschel has suggested, the concept is perhaps best understood as policy designed to structure the conditions for economic conduct and as the opposite of state intervention in economic processes themselves. 
based on the economic constitution, Böhm wrote, "the body of doctrine (Lehrgebäude) of classical economic philosophy had to be translated from the language of economics into the language of legal science. ${ }^{95}$ The idea was that economic science would describe the conditions of complete competition, and this information would provide the standards for legal decision-making. ${ }^{96}$

\section{Law's Roles}

In addition to this substantive dimension, Ordnungspolitik also had a process dimension. In order for a transaction economy to achieve its goals, governmental involvement must itself have certain characteristics and play certain roles. Above all, government could act only to implement the general norms or laws that derived from the economic constitution. Law would provide basic principles of economic conduct, and government officials would have no discretion to intervene in the economy except for the purpose of enforcing those principles.

This conception of the role of law is critical to the entire ordoliberal program. The ordoliberals emphasized that Ordnungspolitik did not permit discretionary governmental intervention in the economy; rather, it required the opposite - legal principles that directed but also constrained government conduct! From a non-ordo perspective, this distinction between governmental "intervention" and constitutional implementation seems suspect, because governmental action necessarily interferes with the economic system to the extent that it creates incentives and disincentives for economic conduct external to those produced by the market itself. One might assume, therefore, that the ordoliberal scheme inevitably creates a highly regulated economy with all the problems of discretion and uncertainty associated with high levels of regulation. The ordoliberals, however, saw no reason why constitutional discourse could not be applied to governmental conduct in the area of economic regulation just as it was to governmental conduct generally. If it is legitimate to ask whether particular governmental conduct conforms to the political constitution, it ought to be legitimate to ask whether such conduct conforms to an economic constitution. Decisions about the legal environment of the market would thus be subject to the economic constitution in the same way that political decisions were subject to the political constitution. As such, they could not "interfere" with the op-

95. Böhm, Wettbewerb und Monopolkampf, supra n. 12, at ix. See also Böhm, Ordnung der Wirtschaft, supra n. 35, at 54.

96. Wilhelm Röpke apparently introduced the concept of "market conformity (Marktkonform) that is frequently used to express this idea. See Wilhelm Röpke, Die Lehre von der Wirtschaft 298 (6th ed. 1951). 
erations of the competitive system because they were, by definition, consistent with that system.

Ordnungspolitik represented an adaptation and transfer of ideas from liberal political theory to the economy. Its roots are in the German political theory of the Rechtsstaat, or "law-based state." ${ }^{\text {97 }}$ Developed in the nineteenth century, this conception of the state focused on the dependability and certainty of the law as a bulwark against abuses of power. It was a means of establishing control over the discretionary power of the sovereign ("If we can't reduce the actual power of the sovereign, we can convince him that he is subject to law"). Central to this image of law is its neutrality and objectivity: the law must be outside the discretion of those wielding governmental power. The state has to provide a basic level of "legal security" (Rechtssicherheit) by assuring that law is knowable, dependable and not subject to manipulation. The ordoliberals used these ideas as the basis for their concept of Ordnungspolitik.

\section{The Principle of Indirect Regulation}

The ordoliberals referred to Ordnungspolitik as "indirect regulation." Government did not "direct" the "processes" of the economy, but merely established "forms" or structural conditions within which those processes could function effectively. ${ }^{98}$ For the ordoliberals, one of the benefits of this concept of "regulation" was that it avoided ad hoc governmental decision-making. If governmental activity relating to the economy was not subject to the ordering function of an economic constitution, they said, it would be beset by problems of inconsistency and self-contradiction. The consequences of any individual action were likely to be counteracted by some other actions, and the probable result would be inefficiency, confusion and, ultimately, economic chaos.99 Ordnungspolitik combatted these problems by requiring the organization of governmental action around the principles of the economic constitution.

The concept of indirect regulation was supported by both "constitutive" and "regulative" principles. ${ }^{100}$ Constitutive principles were the fundamental principles of economic policy for a transaction economy. Their function was to establish the basic "form" of the economy. For Eucken, they included the principles of monetary stability (the

97. See, e.g., Eucken, Grundsätze, supra n. 24, at 48-53. For a detailed discussion of the development of Rechtsstaat theory through the early period of ordoliberal thought, see Friedrich Darmstaedter, Die Grenzen der Wirksamkeit des Rechtsstaates (1930).

98. See Böhm, Ordnung der Wirtschaft, supra n. 35, at 7-9.

99. The ordoliberals often referred to this problem as "Punktualismus," which means, in effect, that the actions affected particular points (Punkte) in the economy without being organized into any coherent whole. See Eucken, Grundsätze, supra n. 24 , at 251.

100. See, e.g., id. at 253. 
need to maintain a stable monetary unit), open markets, private property, contractual freedom, liability (legal responsibility for one's acts) and policy consistency (the need to avoid frequent changes in economic policy). ${ }^{101}$ Regulative principles flowed from constitutive principles and were bound by them, but were more specific and served to maintain the effectiveness of the constitutive principles. For example, the all-important principles of competition law were regulative principles that flowed primarily from the constitutive postulates of open markets and contractual freedom.

This conception of the roles of law in relation to the economy reflected the ordoliberals' deep distrust of the executive branch of government and their confidence in the legislative and judicial branches. In the ordoliberal system, the legislature would make the fundamental decisions about the content of the economic constitution and translate the economic model into normative language. The judiciary would then be responsible for assuring that specific governmental acts were consistent with these basic norms. The executive branch had little power in this scheme; administrators were to follow the dictates of the legislature, and, at least in principle, there was minimal room for discretion.

Implementing the ordoliberal program required a comprehensive view of a community's legal, political and economic systems. For the ordoliberals, all governmental decisions that might affect the economy should flow from the economic constitution. They repeatedly emphasized the need for an "integrated policy perspective (Ganzheitsbetrachtung)" in which each individual decision had to be understood as part of a greater whole from which it received its meaning and effect. ${ }^{102}$ Only thus could the program function effectively. ${ }^{103}$ Monetary, social, labor and trade policy, for example, all had to flow from the same basic principles and support each other.

The ordoliberal conception of Ordnungspolitik also envisioned a community with particular characteristics. The ordoliberals recognized that Ordnungspolitik could be effective only where the members of that community willingly supported it and actively cooperated in implementing it. In their view, economic freedom had its correlate in duty, and community members would have to voluntarily implement the principles they chose in their economic constitution if they

101. Id. at 254-89.

102. "All principles - the constitutive as well as the regulative - belong together. To the extent that economic policy is consistently based on them, a competitive order will be created and made operational. Every principle receives its meaning only in the context of the general blueprint (Bauplan) of the competitive order." Id. at 304. Eucken believed that U.S. antitrust policy had been ineffective precisely because it had not been integrated in a broader policy framework. Id. at 305.

103. See generally, Dürr, supra n. 32 , at $88-9$, and id. at 250 . 
wanted to reap the benefits that the ordoliberal program promised. ${ }^{104}$

\section{The Problem of the Strong State}

In order to accomplish their goals, the ordoliberals called for a strong state, and many have criticized this aspect of their program as an inevitable threat to economic freedom. ${ }^{105}$ For Eucken, Böhm and their colleagues, however, the experience of the Weimar period left no doubt that such a state was necessary. ${ }^{106}$ A weak state could be coopted - as the Weimar state had been - by private economic interests and thus would be unable to create and maintain the conditions of competition. The ordoliberals were convinced that the economy needed the state to protect it, and they placed their full - perhaps inordinate - confidence in the capacity of the legal process to constrain the power of the state.

\section{Competition Law and its Roles}

The keystone of the ordoliberal program was a new type of law called "competition law." While all law relating to the economy should represent Ordnungspolitik, the ordoliberals assigned competition law the direct responsibility for creating and protecting the conditions of competition. This ordoliberal creation has evolved into the European concept of competition law, and without it the development of the European Community is unimaginable. According to a post-war German commentator, "Ordoliberalism moved anti-monopoly policy (Antimonopolismus) to the center of an entire economic system." ${ }^{107}$ The ordoliberals viewed competition law as an indispensable part of their program. Their monetary and other policies designed to foster competition would have little effect, they argued, if firms could act in concert in setting prices or determining output or if firms with economic power could use that power to foreclose opportunities for competition.

\section{A. Evolution of the Idea}

The originality of this competition law idea is often overlooked, but to do so undervalues its importance and influence. The idea of using law to protect competition had been articulated and seriously considered in Austria in the 1890 s, but with minimal theoretical underpinning, and the legislation incorporating the idea was ultimately

104. See, e.g., Eucken, Grundsätze, supra n. 24, at 350-4. See also Bilger, supra n. 11 , at 132 .

105. See, e.g., Uwe Runge, Antinomien des Freiheitsbegriffs im Rechtsbild des Ordoliberalismus (1971).

106. See generally Blum, supra n. 27, at 60-3.

107. Moeller, supra n. 25, at 225. 
defeated. ${ }^{108}$ The idea spread, however, and fostered subsequent legislation. In the 1920s, Germany and several other European states experimented with legislation to control cartels, ${ }^{109}$ but these narrowly focused efforts to impose administrative controls on cartels were not part of a comprehensive program for protecting competition.

The ordoliberals rejected these administrative control measures as fundamentally flawed. ${ }^{110}$ The idea of merely granting authority to the executive branch to combat cartels was doomed, they urged, because those subject to regulation were powerful enough to influence the regulators. Moreover, lacking a reliable conceptual framework and support from other similarly oriented policies, the regulators would have little chance of success.

Nevertheless, for Eucken and his colleagues, history - particularly Weimar history - had demonstrated that competition tended to collapse, because enterprises preferred private (i.e., contractual) regulation of business activities rather than competition and because enterprises were frequently able to acquire such high levels of economic power that they could eliminate competition. The recurring self-destruction of economic freedom, particularly during the 1920s, was the story that informed their thought relating to competition law.

\section{B. The Ordoliberal Conception of Competition Law}

The ordoliberals viewed competition law as a means of preventing this degeneration of the competitive process. ${ }^{111}$ Competition law would "enforce" competition by creating and maintaining the conditions under which it would flourish! The model of complete competition would establish the general principles, and an independent monopoly office would enforce those principles. This fundamentally new conception was a particular application of Ordnungspolitik and rested on its theoretical underpinnings.

The model of complete competition provided the substantive standards for competition law, requiring that law be used to prevent the creation of monopolistic power, abolish existing monopoly posi-

108. See generally Gerber, "The Origins of European Competition Law in Fin-deSiécle Vienna," 36 Am. J. Leg. Hist. 405 (1992). The idea of attacking cartel arrangements under principles drawn from the law of obligations (i.e., generally, tort and contract principles) was developed in several late nineteenth century cases before the Reichsgericht, but this approach proved generally unsuccessful. See, e.g., Rainer Schröder, Die Entwicklung des Kartellrechts und des kollektiven Arbeitsrechts durch die Rechtsprechung des Reichsgerichts vor 1914 (1988).

109. See generally Riesenfeld, "The Protection of Competition," in American Enterprise in the Common Market 197, 207-94 (Eric Stein \& Thomas Nicholson eds. 1960) and Kronstein \& Leighton, "Cartel Control-A Record of Failure," 55 Yale L. J. 297 (1946).

110. See, e.g., Böhm, Wettbewerb und Monopolkampf, supra n. 12, at 363-70.

111. Id. at 369-70. 
tions where possible and, where this was not possible, control the conduct of monopolies. This conception of competition law focused attention on one core problem - private economic power. ${ }^{112}$ From the ordoliberal perspective, such power necessarily threatened the competitive process, and the primary function of competition law was to eliminate it or at least prevent its harmful effects. This broad conception of economic power is one of the features of German and European competition law thinking that most clearly distinguishes it from its U.S. antitrust law analogues.

\section{Prohibiting Monopoly}

One component of competition law was directed at the structures of monopoly power. A monopoly prohibition was designed to prevent or eliminate the economic power that by its very existence distorted the competitive order. A firm or group of firms that had power over price or the power to hinder the performance of its rivals was structurally inconsistent with the complete competition standard.

The monopoly prohibition was directed primarily at cartels and other agreements between competitors. Such agreements created the very power that threatened the competitive process and, therefore, had to be prohibited. The ordoliberals had witnessed the destructive influence of cartels on the German economy, polity and society during the Weimar period, and they considered a prohibition of cartel agreements to be necessary for the maintenance of a competitive economy. ${ }^{113}$ This prohibition was the most politically and economically significant component of competition law and, at least theoretically, the easiest to implement. It was most important because cartels had become a dominant force in Germany, and an attempt to prohibit them would thus have widespread and intense economic impact. It was relatively easy to implement because it merely called for a prohibition of agreements that had particular characteristics and effects. The agreements were themselves the structural harm; if they could be effectively prohibited, the harm would be eliminated.

Where a monopoly position was not based on agreement between competitors, the task of competition law was more complicated. Even when government policy maintained the basic conditions of competition, single firms could acquire monopoly power. This could occur, for

112. Franz Böhm's pathbreaking article on this subject was published in 1928. See Böhm, Das Problem der privaten Macht, supra n. 52.

113. The demand for an absolute prohibition of horizontal agreements was closely associated with the ordoliberals (particularly Franz Böhm). For decades after the Second World War (and until very recently) the European discussion of these issues centered on the distinction between the "prohibition principle (Verbotsprinzip)" that was associated primarily with Germany and the ordoliberals and the "abuse principle (Missbrauchsprinzip)" that characterized administrative control systems. See generally Gerber, "Law and the Abuse of Economic Power in Europe," 62 Tulane L. Rev. 57, 64-6 (1987) [hereinafter Gerber, Abuse of Economic Power]. 
example, in cases of natural monopoly - such as utilities - where the market could not sustain more than one enterprise. It could also occur where one firm had won the competitive battle and had acquired sufficient power to block or discourage attempts at competition by rivals or potential rivals. Ordoliberals generally agreed that, if possible, monopoly power should be eliminated, and thus competition law had to be able to require firms to divest themselves of components of their operations. ${ }^{114}$ This concept created far more significant interference with private property than firms in Europe had experienced, except in wartime, and was, therefore, highly controversial. Moreover, its proponents tended to be vague about how it would work, in part because of the controversy and in part because they assumed that divestiture would seldom be necessary.

\section{Conduct Control}

\section{The As-if Standard}

Divestiture would not be required in cases of natural monopoly or monopoly based on a legally protected right (for example, a patent or copyright), or when divestiture would otherwise be impractical or entail economic waste. ${ }^{115}$ In such cases, competition law was to provide a standard of conduct for the firms involved. This standard was arrestingly simple. It required that economically powerful firms act as if they were subject to competition - i.e., as if they did not have monopoly power. ${ }^{116}$

The idea was appealing. It promised - through a single objective legal mechanism - to limit the harms associated with both private economic power and state intervention. Application of the as-if standard required that firms refrain from conduct that would be unavailable to them if they had no monopoly power. They were to be limited, therefore, to conduct that was consistent with complete competition. They would not be allowed to use their power in ways harmful to competitors or to society in general.

According to the ordoliberals, the as-if standard would not create the danger of governmental intervention. It was conceived as an objectively applicable measure that in most cases would provide clear

114. See Entwurf zu einem Gesetz zur Sicherung des Leistungswettbewerbs und zu einem Gesetz über das Monopolamt (Bundeswirtschaftsminister pub. 1949) $\$ \S 15-16$ [hereinafter Josten Draft]. For discussion of this so-called "Josten Draft," see infra, text accompanying note 156-8. For Böhm's views, see Dümchen, supra n. 91 , at 80-4.

115. See Josten Draft, id. at \$§ 17-20.

116. Leonhard Miksch, a leading student of Walter Eucken, was chiefly responsible for elaborating and refining this idea. See, e.g., Leonhard Miksch, Wettbewerb als Aufgabe: Grundsätze einer Wettbewerbsordnung (2nd ed. 1947) [hereinafter Miksch, Wettbewerb als Aufgabe] and "Die Wirtschaftspolitik des Als Ob," 105 Zeitschrift für die gesamte Staatswissenschaft 310 (1949) [hereinafter Miksch, Die Wirtschaftspolitik]. Not all ordoliberals were enthusiatic about the "as-if" standard. 
guidance. Because the monopoly office would be authorized merely to apply this standard, the law would not give regulators discretionary power to intervene in the economy. The idea promised, therefore, to deal simultaneously with the dual evils of uncontrolled political power and unrestrained economic power.

\section{The Idea of Performance Competition}

The concept embodied in the as-if standard was based on a legal distinction that was developed in the 1920 s and continues to be central to German competition law. In applying the German statute against unfair competition (UWG), a leading scholar named H.C. Nipperdey had perceived a distinction between "performance competition (Leistungswettbewerb)" and "impediment competition (Behinderungswettbewerb)."117 The former included conduct that made a firm's products more attractive to consumers, typically by improving their characteristics or lowering their prices; while the latter referred to conduct designed to impede a rival's capacity to perform.

Franz Böhm and other ordoliberals borrowed this distinction and placed it at the center of their new conception of competition law.118 Performance competition was consistent with the competitive model, they said, because under competitive conditions, performance improvement was the sole means by which a firm could improve its profits. Where, however, a firm. used its power to impede the performance of a rival - e.g., by excluding the rival from the market - it was interfering with the competitive process, and the state should prevent such conduct. In effect, the as-if standard prohibited impediment competition. Böhm's early work had focused on analyzing the characteristics of competition by economically powerful firms, and he had identified several categories of conduct that represented "impediment" or "non-performance" competition. ${ }^{119}$. These included, for example, predatory pricing, boycotts and loyalty rebates. In each case, he considered the conduct inconsistent with the as-if standard, because a firm would not be able to engage in such practices unless it had monopolistic power. ${ }^{120}$

117. Nipperdey, "Wettbewerb und Existenzvernichtung," 1930 Kartell-Rundschau 128 (1930).

118. See, e.g., Böhm, Wettbewerb und Monopolkampf, supra n. 12, at 178.

119. Böhm, id. at 250-6, 291-317.

120. There was little agreement among ordoliberals with regard to oligopoly situations in which a small number of firms dominated a market and, as a result, could exercise power over rivals through consciously parallel conduct. Leonhard Miksch argued that in this situation the government's only means of opening the market and eliminating the oligopoly was to regulate the market, particularly through controls on prices. This, he believed, would prevent large firms from using their collective dominance of the market to eliminate competition from smaller firms. See Miksch, Wettbewerb als Aufgabe, supra n. 116, at 91.

This solution was, however, criticized by some ordoliberals as impracticable. Eucken considered it unnecessary, provided that the controls on monopolies were suffi- 


\section{E. Application and Enforcement}

Many of the procedural aspects of the ordoliberal conception of competition law were as distinctive and original as their substantive counterparts. The ordoliberal vision included a specific institutional framework for creating, applying and enforcing its substantive provisions. The legislature would enact a competition law based on the economic constitution, an independent monopoly office would assure compliance with that law, and, when necessary, the judiciary would supervise interpretation of the principles by the cartel office. ${ }^{121}$ The executive branch of government was to play virtually no role in this scheme.

The ordoliberals assigned an important, but comparatively simple, role to the legislature. It was to translate into normative terms the economic principles embodied in the model of complete competition. ${ }^{122}$ This entailed drafting a statute that identified deviations from the competitive model as violations of legal norms, thus implementing the "economic constitution" by imbedding its principles in the legal system. This conception of the legislature's role was designed to protect the legislative process from political pressures. The existence of an economic constitution gave the legislature relatively little discretion in fashioning a competition law, because once the constitutional decision in favor of the competitive "order" had been made, the complete competition model itself generally dictated the provisions of the statute. As a consequence, there would also be little incentive for private interests to attempt to influence legislative decisions.

The most original procedural component of the ordoliberal model was the enforcement of competition law by an autonomous monopoly office. This concept was new, deriving neither from prior European experience nor from U.S. antitrust law. According to Eucken, "In the situation of the modern industrial state this great, central figure of the monopoly office had to appear. Without it the competitive order and with it the modern "Rechtsstaat" is threatened. The monopoly office is as indispensable as the highest court."123

The monopoly office would have sole responsibility for enforcing this new type of law. It would both investigate alleged violations of the statute and initiate investigations on its own. When it found vio-

ciently strict. He believed that firms would not be likely to engage in impediment competition if this would give them monopoly power and thereby subject them to the highly restrictive as-if conduct standard. Eucken, Grundsätze, supra n. 24, at 298-9.

121. "One of the essential characteristics of the ordoliberals is their great distrust of the executive and their no less great confidence in the legislative and the judiciary." Bilger, supra n. 11, at 150.

122. The legislation was to be "simple and realistic." Eucken, Grundsätze, supra n 24 , at 298.

123. Id. at 294. 
lations, it would have the authority to take certain enforcement actions. These included, for example, invalidating cartel contracts and ordering the termination of particular conduct, in some cases with the threat of fines for failure to comply. The actions of the office were subject to review by the regular courts for conformity to the economic constitution.

The most important - and most controversial - characteristic of this office was its autonomy. It was not intended merely to be a part of the state bureaucracy and hence subject to political influence. The ordoliberals had witnessed during the Weimar period the ability of cartels and large corporations to eviscerate attempts at control by putting political pressure on the executive branch, and they were convinced that this new office had to be autonomous in order to avoid such influences. ${ }^{124}$ They envisioned it as a quasi-judicial office, guided not by political considerations, but by the application of judicial methods to authoritative texts.

For the same reasons, the monopoly office would also have to be made into a strong institution. It would need significant enforcement authority, so that it could effectively demand compliance, and the resources necessary to operate quickly and decisively and to attract and maintain personnel of the highest caliber. The personnel issue was particularly important from the ordoliberal perspective, because in that view the function of the monopoly office was to apply a "scientific" test. It would have relatively little discretion, because informed application of the economic criteria would provide the answers to most questions. It thus needed career specialists with a high level of economic and legal training who would be protected from outside political or pecuniary influences. Eucken did not expect the monopoly office to handle large numbers of cases, because he believed that a consistent and comprehensive Ordnungspolitik would keep markets open and reduce to a minimum instances of monopoly creation. $\mathrm{He}$ did, however, believe that the office would have to send a clear message to firms that it would enforce these regulative principles strictly.

The role envisioned for the judiciary in this scheme was limited, but important. The courts were to be available to assure that decisions of the monopoly office correctly interpreted the competition statute and conformed to the economic constitution. ${ }^{25}$ Actions of the monopoly office were, therefore, made reviewable by the regular courts rather than the administrative courts in order to emphasize the autonomous role of law in the ordoliberal program. The actions of the monopoly office did not represent ordinary administrative action that administrative courts could review to determine whether discre-

124. See generally, Bilger, supra n. 11, at 159.

125. Eucken, Grundsätze, supra n. 24, at 307. 
tion had been abused. Rather, the monopoly office would apply legal principles according to objective standards; there was not supposed to be any discretion. Here again the image of the Rechtsstaat plays an important role in informing the content of the ordoliberal program.

\section{The Integrity of the Ordoliberal Program}

The ordoliberal program thus represented a well-developed and highly integrated whole. The theoretical and methodological premises generated a set of interpretative principles about the economic system, which, in turn, were tied directly to specific substantive and procedural proposals. It integrated sophisticated analytical contributions with practical policy initiatives, utilized the concept of an "economic constitution" as its primary integrative tool.

The intellectual dimension of the program focused on what the ordoliberals considered a new method of understanding economic reality, and this methodological and philosophical component of the program broadened and deepened its impact and established a fundament on which to build an integrated policy framework. Eucken's concept of "Ordnung" provided a construct that served to organize data about the economy and to elucidate the interrelationships among the components of an actual economic system, and it promised new levels of certainty and dependability in dealing with the economy.

The introduction of legal-constitutional discourse added a critical dimension to these insights by recoding them as a framework for the articulation of policy. Laws determined the conditions and structures within which market processes operated, and thus economic knowledge had to be translated into the language of law. At the core of the ordoliberal program is the symbiotic character of the relationship between legal and economic processes.

Law's roles were shaped by the characteristics desired for the economic system, but those characteristics were, in turn, shaped by the characteristics of the political and social system that was sought. The market economy could work properly only if the laws related to it were applied within a constitutional framework, and this framework would then assure that government could not interfere with the operations of the economy.

Competition law was the institutional anchor for the ordoliberal program, and it was also tightly interwoven with the theoretical component of the system and with the overall constitutional framework. Its role was to assure that firms did not create monopoly power or use it to distort the competitive system, and in this sense its substantive principles derive from ordoliberal economic insights. Competition law's roles were circumscribed by the principles of the economic constitution, however, so that the legal regime did not generate opportu- 
nities for government to interfere in the economy. According to the ordoliberals, competition law could only be effective where it was part of the larger framework of "Ordnungspolitik". While emphasizing that competition law was necessary as part of an overall framework of economic policy, Eucken continually warned that standing alone it would be of little or no value.

The exceptional degree of integration in the ordoliberal program between intellectual and policy dimensions and between legal and economic processes is impressive by any measure. It was facilitated, and perhaps made possible, by the unique situation in which a small band of intellectuals managed to operate for years without the need to make political or doctrinal compromises or even to consider fitting their ideas into the existing political and economic framework. This situation allowed them to develop a remarkably comprehensive and tightly integrated theoretical perspective and concomitant policy language.

This high level of integration undoubtedly played an important role in the success of the program, but it was not without risks. If the Nazi regime were not soon defeated, the ordoliberals would, at best, have wasted a decade or more of effort; at worst, many of them would have lost their lives and/or livelihoods. Furthermore, if, as they believed, that regime would soon be defeated, the very comprehensiveness and integration of their program might well represent serious obstacles to achieving influence. The ordoliberals did not offer an assortment of recipes from which a post-war regime could pick and choose a few elements. The ordoliberals argued that such a regime would have to take their entire program - from intellectual perspective to policy prescriptions.

\section{Ordoliberalism and the Shaping of Modern Germany}

When the war did end, there seemed little likelihood that ordoliberal ideas would become influential. Throughout Europe, liberalism had been so thoroughly discredited that very few wished to be associated with it. Virtually everywhere, socialist solutions had captured the public imagination and the fancy of intellectuals. Rage at the governments whose conduct had caused such havoc during the preceding decades and desire for increased access to political and economic power fueled this enthusiasm for socialism. In Germany, in addition, the importance of the "Volk" and the excoriation of individualist values that had dominated thought for more than a decade generated a predisposition for collective solutions in many social groups. 
The adoption of some form of socialism thus seemed all but inevitable in Germany. ${ }^{126}$ The Marxist socialism of the Social Democratic Party had a solid base of working class support in many areas of Germany, and many of its leaders from the pre-Nazi period had returned from exile to provide leadership. ${ }^{127}$ Christian socialism also had strong support. The Church as an institution seemed to promise not only material support but also moral strength during a period when both were in great need, and, particularly in Roman Catholic areas, socialism based on Christian values became popular.

\section{A. The Postwar Period and the Dynamics of Occupation}

The ordoliberals began immediately after the war to try to change this situation. They began to produce an extraordinary spate of books, pamphlets and articles directed primarily at Germany's intellectual and political leaders. ${ }^{128}$ In 1948, for example, Eucken and Böhm together founded the famous ORDO journal, which became exceptionally influential as a forum for debate about economics and economic policy. Many ordoliberals also pursued their goals on the popular level. For example, the Frankfurter Allgemeine Zeitung, perhaps the leading national newspaper of the period, was controlled by ordoliberals and effectively disseminated ordoliberal principles. ${ }^{129}$ Members of the group also spoke widely to numerous groups on behalf of their program, propagating their ideas to whomever would listen. Fortunately, many of them knew how to present their message in a form that made it accessible to the general population. Franz Böhm, for example, also played the role of politician as a member of the Bundestag for two terms (1953-61).

The special circumstances of the postwar period provided the ordoliberals with exceptional opportunities to propagate their ideas and put them into practice. The Nazi regime had been crushed, and there was widespread recognition of the need for a fundamental change. Reconstruction was called for, and the ordoliberals were among the few in Germany in a position to provide a well-developed program for such reconstruction. ${ }^{130}$

126. See generally Salin, "Wirtschaft und Wirtschaftslehre nach zwei Weltkriegen," 1 Kyklos 41 (1947) and Blum, supra n. 27, at 13-38.

127. See, e.g., Dieter Klink, Vom Antikapitalismus zur Sozialistischen Marktwirtschaft: Die Entwicklung der Ordnungspolitischen Konzeption der SPD von Erfurt (1891) bis Bad Godesberg (1959) 65-134 (1965).

128. For a review of this literature, see Dürr, supra n. 32, at 13-5.

129. Bilger, supra n. 11 , at 269.

130. "How fortunate and valuable [Eucken's] quiet impact had been even during the National socialist period became clear only after its collapse, as the circle of his friends and students in Germany emerged as the most important support for economic reason." von Hayek, "Die Uberlieferung der Ideale der Wirtschaftsfreiheit," 31 Monatshefte 333, 7 (1951). 
The structures of political power during the occupation of Germany further facilitated the reception of ordoliberal thought. The military governments of the occupying states maintained ultimate authority within German territory until 1949, when the Federal Republic was created, and full sovereignty was not returned to Germany until 1955. This meant that German administrative officials were subject to approval by occupation authorities, as were most important economic and political decisions. Moreover, the ordoliberals' record of opposition to nazism favored their access to positions of leadership. By 1947, economic policy authority for the British and American zones of occupation had been unified under U.S. leadership, and the strong market-orientation of U.S. officials led them to secure important posts for ordoliberals and provide institutional support for their ideas. ${ }^{131}$

The rupture of cooperation between the Soviet Union and the other occupation authorities that led to the cold war intensified U.S. support for ordoliberal proposals, as economic structure and policy quickly became part of the East-West conflict. The United States sought to demonstrate the superiority of its free market-based social system by demonstrating its success in Germany. ${ }^{132}$ This dynamic also impelled efforts to make the German test case as "pure" a capitalist economy as possible, on the theory that the "purer" it was, the stronger the proof that the market economy was superior to its socialist competitor. ${ }^{133}$

The access of ordoliberals to administrative and economic advisory institutions enhanced the effectiveness of their efforts to propagate their ideas. For example, ordoliberals represented more than fifty percent of the members of the Academic Advisory Council (Wissenschaftlicher Beirat) that was formed in 1947 to give advice to the government and that had great influence on the development of policy. ${ }^{134}$ In addition, numerous ordoliberals occupied prominent positions in economic policy divisions of German self-government institutions. ${ }^{135}$

These efforts of the ordoliberals soon achieved success on the intellectual level. Within a few years after the end of the war, ordoliberal methods, ideas and values had become the starting point for most serious thinking about economic policy. High-ranking gov-

131. See generally Blum, supra n. 27, at 184-215.

132. See id. at $182-4$.

133. Id. at 6.

134. See Bilger, supra n. 11, at 211. For discussion of the activity of this group, particularly in regard to the relationship between theory and practice, see von Beckerath, "Der Einfluss der Wirtschaftstheorie auf die Wirtschaftspolitik," in Logik der Sozialwissenschaften 497, 502-9 (Ernst Topitsch ed. 1966).

135. Leonhard Miksch, for example, was a director of economic policy planning in the bizonal administration. See Gerold Ambrosius, Die Durchsetzung der sozialen Marktwirtschaft in Westdeutschland 1945-1949 at 114 (1977). 
ernment officials and academics in these areas (the overlap between these two groups was significant) generally had accepted the central notions of ordoliberalism.

\section{B. The Social Market Economy and the Road to Political Success}

In the longer term, however, the issue was whether these ideas would find broad-based support within the German population and, in particular, within the emerging political parties. In the western zones of occupation, political activity was allowed to resume soon after war's end. Parties emerged or re-emerged in 1946 in most areas, and elected assemblies with limited rights were formed by 1947 . It was in these parties that the future of Germany would be shaped, and many of the central elements of the ordoliberal program acquired enormous influence in that evolutionary process. In this context, ordoliberal ideas achieved their influence primarily as part of a broader program known as the social market economy.

This set of ideas, as originally developed by Müller-Armack, ${ }^{136}$ incorporated central components of the ordoliberal program such as the concepts of "economic constitution" and Ordnungspolitik, and it emphasized the need for laws to protect the process of competition. ${ }^{137}$ He imbedded these ideas, however, in an idiom that placed greater emphasis on social values and concerns. For him, the economic benefits of Ordnungspolitik were valuable - even necessary - in themselves, but his focus was on their roles in unifying and integrating German society. ${ }^{138}$

The social market economy became a political program in the context of the evolution of the Christian Democratic party (CDU). ${ }^{139}$ This party emerged during the post-war period as the primary representative of the middle class and of Catholic workers. Immediately after the war, christian socialism was the prevailing credo within the party, and during 1946 and 1947 a struggle ensued within the party to define a platform that appealed to both the middle and working

136. See supra, text accompanying nn. 31-2. For discussion of Müller-Armack and his roles and ideas, see Watrin, "Alfred Müller-Armack: 1901-1978," in Kölner Volkswirte und soziale Wissenschaftler 39 (Christian Watrin ed. 1988). For description and analysis of the development of social market economy ideas, see Alfred MüllerArmack, Genealogie der sozialen Marktwirtschaft (1974) (hereinafter Müller-Armack, Genealogie] and Watrin, "The Principles of the Social Market Economy: Its Origins and Early History," 135 Zeitschrift für die gesamte Staatswissenschaft 405 (1979).

137. See, e.g., Müller-Armack, id. at 29.

138. "The social market economy is the first historically successful attempt to bring the comprehensive possibilities of personal freedom into accord with a performance-based society (Leistungsgesellschaft) with social and communitarian goals. Id. at 8.

139. See generally, Geoffrey Pridham, Christian Democracy in Western Germany (1977) and Arnold J. Heidenheimer, Adenauer and the CDU (1960). 
classes. ${ }^{140}$ Under these circumstances, the concept of the social market economy appealed to many leaders of the CDU. At the very least, it was a promising political symbol that in three words appealed to those interested in the market economy, those concerned about receiving a fair share of the social product and all who sought to unite and integrate the nation. Moreover, the substantive elements of the program promised the prosperity that all considered essential, while emphasizing the politically attractive message that this had to be done in the context of social improvement for all members of society.

The decisive event in the success of the social market economy occurred in 1948. In the midst of the severe economic difficulties of the reconstruction period, Ludwig Erhard - the highest official in German self-government, a member of the CDU and an ardent and vocal supporter of ordoliberal and social market economy ideas ${ }^{141}$ took an extraordinary step. Without the required formal approval of the U.S. authorities (though with tacit support from the U.S. commander - Gen. Lucius Clay - whose approval was necessary) he eliminated virtually overnight most rationing and price controls in Germany. ${ }^{142}$

At first, many observers saw this bold move as unlikely to succeed and probably foolhardy. Erhard was, for example, heavily criticized for the inflation that followed his termination of price controls. Moreover, for several months it seemed that Erhard's critics might be right. But Erhard's gamble did work. ${ }^{143}$ By the end of the first year the economic situation had changed completely. Prices had stabilized, and employment, profits and investment had improved dramatically. This began a period of continued growth and improvement that has lasted with few interruptions until today. The so-called "German miracle" had begun.

The success of Erhard's action soon generated widespread support for his party and enthusiasm for his social market economy ideas. In 1949 the CDU adopted many of the central principles of the social market economy in its "Düsseldorf platform" (Düsseldorfer Leitsätze), ${ }^{144}$ and some version of those ideas has been part of the CDU program ever since. This was particularly important, because

140. See, e.g., Bilger, supra n. 11, at 248-63, and Rolf Wenzel, Adenauer und die Gestaltung der Wirtschafts- und Sozialordnung im Nachkriegsdeutschland 38-108 (1983).

141. Erhard had spent the Nazi years as an economics professor in Nürnberg, where he became a supporter of the ideas of the Freiburg School. For discussion of Erhard's thought and the formative influences on it, see Christof Heusgen, Ludwig Erhards Lehre von der sozialen Marktwirtschaft (1981).

142. See generally, e.g., Henry C. Wallich, Mainsprings of the German Revival 11352 (1955).

143. For discussion, see "Symposium: Currency and Economic Reform - West Germany After World War II," 135 Zeitschrift für die gesamte Staatswissenschaft 301404 (1979).

144. Blum, supra n. 27 , at 280 . 
the CDU was the governing party in western Germany from then until 1966, and thus those principles were the primary economic policy guidelines in Germany for almost two decades. When the Federal Republic of Germany (FRG) was established in 1949, Konrad Adenauer of the CDU was named its first chancellor, and Ludwig Erhard became its minister of economics, a post he held until 1963, when he replaced Adenauer as chancellor.

Erhard interpreted Germany's economic successes during this period as a direct result of applying social market economy ideas, especially those most closely associated with ordoliberalism. ${ }^{145} \mathrm{He}$ repeatedly and forcefully propagated this interpretation, and his personal popularity and influence over the development of German economic policy gave that interpretation massive impact. ${ }^{146}$ Of the leading proponents of the social market economy, Erhard was probably closest to the ordoliberals. He ascribed particular importance to the concept of the economic constitution as a means of structuring the relationship between government and the economy, and he viewed competition law as vital to the success of the social market economy. ${ }^{147}$

\section{Ordoliberalism and German Competition Law}

The ordoliberal conception of competition law has played a key role in the success of the social market economy in Germany and in the evolution of German thought and attitudes about economy and society. It has been a major vehicle for disseminating and focusing attention on ordoliberal ideas, and it has helped to create and maintain the competitive conditions that have fueled the German economy. Ordoliberals conceived German competition law and long remained closely associated with it. They created its intellectual framework as well as the discourse in which it is imbedded, they led the fight for enactment of the German competition law statute, and they have played central roles in implementing it.

\section{A Case of Mistaken Identity}

Unfortunately, the role of these ideas has been obscured, particularly in the United States, by the peculiar circumstances in which German competition law was created. There is a widely-held assumption that German competition law was based primarily on United States antitrust law and thus represents merely an adapta-

145. See, e.g., Ludwig Erhard, Prosperity through Competition (1958).

146. ". . .the economic policy shaped into the mid-1960's by Ludwig Erhard, was quite consciously pursued as Ordnungspolitik." Heuss, supra n. 76, at 23.

147. For discussion, see Heusgen, supra n. 141, at 144-238. 
tion of those ideas. ${ }^{148}$ This misperception requires correction, because it clouds the dynamics of German and, ultimately, European competition law.

Several factors have contributed to this distortion. One is the existence of Allied decartelization laws. On the basis of a widespread belief that cartels had played an important role in the success and course of nazism, the Western allies introduced decartelization laws soon after the end of the war. ${ }^{149}$ These laws were broadly similar, focusing primarily on prohibiting cartels, and they were based on U.S. antitrust law.150 This has led many to assume that these laws served as a model for German competition law. ${ }^{151}$ Moreover, some have seen support for this assumption in the requirement in the treaty returning sovereignty to Germany that the decartelization laws remain in effect until the new government enacted a competition law.

As we have seen, however, the lineage of German thinking concerning competition law has little to do with this scenario. The ordoliberals created the intellectual framework for competition law long before the end of the Second World War and with minimal reference to U.S. antitrust experience. ${ }^{152}$ The decartelization laws had little influence on the development of this body of thought. They were generally viewed as alien to the German legal system, and seldom were of sufficient practical importance for German lawyers or businessmen to study them carefully. ${ }^{153}$ Similarly, the requirement that Germany enact a competition law after the end of the occupation was of secondary importance, because there was already general agreement in Germany that a competition law of some kind should be enacted.

This is not to say that U.S. antitrust law has played no role in the development of German competition law. German scholars, legislators and administrators did look to U.S. antitrust experience in

148. See, e.g., Davidow, "The Worldwide Influence of United States Antitrust," 35 Antitrust Bull. 603 (1990).

149. For discussion, see Bock \& Korsch, "Decartelization and Deconcentration in the West German Economy since 1945," in Antitrust Laws: A Symposium 138-53 (Wolfgang Friedmann ed. 1953) and Wernhard Möschel, Das Recht der Wettbewerbsbeschränkungen 21-2 (1983).

150. There was a widespread belief that these laws were merely an attempt to weaken Germany as a potential economic competitor. See, e.g., Blum, supra n. 27, at 191-5.

151. See, e.g., Goldstein, "Effect of Foreign Antitrust Laws on United States Business," 12 Southwestern L. J. 405, 408 (1958).

152. Although there was relatively little detailed knowledge of United States antitrust law in Germany prior to the end of the war, the general impression seems to have been that the U.S. law was a failure, and this impression obviously would not have inspired emulation. See, e.g., Eucken, Grundsätze, supra n. 24, at 292.

153. German lawyers and administrators' who encountered these laws generally found them "strange". Blum, supra n. 27, at 196. 
drafting specific provisions of the German competition law, ${ }^{154}$ and since the enactment of that statute, they have often looked to U.S. antitrust law as a basis for comparison and a source of ideas for resolving specific problems. ${ }^{155}$ The important point, however, is that the conceptual foundations and much of the discourse of that legal regime were indigenous products, not borrowings from the United States. U.S. ideas have been absorbed into an intellectual tradition with its own dynamics - they did not provide the structures of that tradition.

\section{The Evolution of German Competition Law}

The ordoliberals began to call for a competition law very soon after the end of the war. In 1947, Ludwig Erhard appointed a group of scholars and officials, most of whom were closely associated with ordoliberalism, to draft a competition law. ${ }^{156}$ Not surprisingly, the draft they submitted in 1949 was based on existing ordoliberal proposals. ${ }^{157}$ It called for an absolute prohibition of cartels, sought generally to prohibit conduct other than "performance competition," and established an independent monopoly office whose role was to enforce these provisions. This so-called "Josten draft" was ultimately rejected by Ludwig Erhard on the grounds that it was too radical for the political circumstances, but it set the general direction for the many drafts that were to follow. 158

The fight for a competition law lasted almost a decade, during which more than twenty separate legislative drafts were submitted. ${ }^{159}$.The main protagonists in the battle were the ordoliberals and social market economy adherents in government and in the universities, on the one hand, and German industry, on the other. The ordoliberals also found support in currents of antimonopolism within the socialist parties, as well as among some conservatives concerned with protecting small business. ${ }^{160}$ The conflict centered on the issue of whether the law should contain an absolute prohibition of cartels and other horizontal agreements. The ordoliberals and their allies

154. Allied governments apparently "intervened in the legislative process until about 1953." Möschel, supra n. 86, at 153.

155. See, e.g., Mestmäcker, "Diskriminierungen, Dirigismus und Wettbewerb," 1957 Wirtschaft und Wettbewerb 21.

156. For discussion, see Günther, "Die geistigen Grundlagen des sogenannten Josten-Entwurfes," in Wirtschaftsordnung und Staatsverfassung: Festschrift für Franz Böhm 183 (1975).

157. See Josten Draft, supra n. 114.

158. For discussion of the intellectual context, see Fikentscher, "Die deutsche Kartellrechtswissenschaft 1945-1954," 1955 Wirtschaft und Wettbewerb 205.

159. For detailed discussion of this legislative process, see Rudiger Robert, Konzentrationspolitik in der Bundesrepublik-Das Beispiel der Entstehung des Gesetzes gegen Wettbewerbsbeschränkungen (1976).

160. See generally Blum, supra $n .27$, at $32-8$. Even the social democratic party supported competition law efforts. See id. at 258-60. 
considered such a prohibition necessary, but German industry was fundamentally opposed to it. Industrial leaders were willing to accept an abuse statute similar to that enacted during the Weimar period, but insisted that a competition law not go beyond such administrative control measures.

This highly visible and protracted battle played a prominent role in the state-building process in Germany. The cartel issue involved basic questions about the characteristics of West German society and about its relationship to the pre-war regimes in which cartels had played such major roles. As a result, it was often a focus of public attention. The controversy thus assisted the dissemination of ordoliberal and social market economy ideas. ${ }^{161}$ Moreover, ordoliberal attacks on cartels were a major factor in changing wellestablished public attitudes in favor of cartels.

In 1956 the two sides reached a compromise that led to the enactment of the Law Against Restraints on Competition (Gesetz gegen Wettbewerbsbeschränkungen - GWB). ${ }^{162}$ The basic structures and the vocabulary of the act - which is still in effect - reflect strong ordoliberal influence. The GWB calls for a prohibition of cartels, as had been so vigorously demanded by the ordoliberals for so long. It also includes a variety of measures aimed at preventing the abuse of economic power, including a variant of the quintessentially ordoliberal "as-if" standard of conduct. ${ }^{163}$ The law's procedural mechanism is also ordoliberal (and far from U.S. ideas) in that it creates a relatively autonomous office - the Bundeskartellamt or Federal Cartel Office (FCO) - to enforce the law and virtually excludes private antitrust suits.

The compromise reached with German industry included, however, exceptions to many of these basic principles that were designed to reduce the potential negative impact of the law on the competitiveness of German business. ${ }^{164}$ Most important were the numerous exceptions to the prohibition of cartels, which permitted so-called "crisis cartels," standardization agreements and a variety of other horizon-

161. "Since then [the enactment of the GWB] ordoliberalism has been inextricably tied to Böhm's conceptual model of the (absolute) prohibition of monopoly. . . ." Behlke, supra n. 48 , at 57 n.89.

162. Gesetz gegen Wettbewerbsbeschränkungen [GWB], 1957 Bundesgesetzblatt [BGB1.] 1081 (Ger.). See, e.g., Schwartz, "Antitrust Legislation and Policy in Germany - A Comparative Study," 105 U. Penn. L. Rev. 617 (1958). The leading commentary on German competition law is Ulrich Immenga \& Ernst-Joachim Mestmäcker, Kommentar zum GWB (2d ed. 1992). For three leading treatises, see Fikentscher, supra n. 2; Wernhard Möschel, supra n. 149; and Fritz Rittner, Wirtschaftsrecht (2d ed. 1988). For a useful comparative discussion, see James A. Maxeiner, Policy and Methods in German and American Antitrust Law (1986).

163. For discussion, see Immenga \& Mestmäcker, id. at 734-7.

164. See Kartte \& Holtschneider, "Konzeptionelle Ansätze und Anwendungsprinzipien im Gesetz gegen Wettbewerbsbeschränkungen-Zur Geschichte des GWB," in Handbuch des Wettbewerbs 193, 207-10 (Helmut Cox et al., eds. 1981). 
tal agreements, at least under certain conditions. The compromise was a disappointment to ordoliberals and social market adherents such as Ludwig Erhard, ${ }^{165}$ but at least they had achieved their basic goal. Enactment of the GWB probably ranks as the most important political victory for ordoliberalism. ${ }^{166}$

Amendments to the GWB during the 1970s and 1980s significantly strengthened its impact. ${ }^{167}$ In 1973 , for example, provisions were added requiring pre-merger notification and enabling the FCO to combat mergers and acquisitions that created or strengthened a market-dominating position. Provisions enhancing the FCO's authority to combat such abuses were also added during this period, as was the office of the monopoly commission - a five-person group of academics and practitioners with the task of analyzing and commenting on the development and application of competition law.

\section{The Roles of Competition Law}

Despite its compromises, German competition law became, and has remained, an important factor in German legal and economic life. It is, at least arguably, the most stringently applied competition law in the world. The FCO has become an active and highly-respected institution, attracting and retaining many highly-qualified lawyers and economists and maintaining a high degree of autonomy. As a result, businesses, particularly larger firms, must pay close attention to the rules enforced by the FCO, and competition law has become an important legal subject in practice as well as in law faculties. Competition law has thus become the central institutional anchor for ordoliberal ideas, and its practical importance continues to reinforce the power of those ideas. From the beginning, the FCO itself has been heavily influenced by ordoliberal ideas. For example, Eberhard Günther, president of the FCO from its inception until 1972 was an admirer of ordoliberal thought and frequently instituted procedures and followed interpretations based on it. Those procedures and principles have become part of the culture and practice of the office, even if they are today somewhat less obviously and less self-consciously associated with ordoliberalism.

Ordoliberalism has also continued to dominate the central intellectual tradition within the field of competition law. Most leading scholars in the area of competition law have been closely associated with ordoliberalism, and this is particularly important because academics play major roles in German competition law. The strength of this tradition even on a personal level is striking. One of Franz

165. Giersch, "Liberal Reform in Western Germany," 39 ORDO 3, 8 (1987).

166. Blum, supra n. 27, at 284.

167. See, e.g., Zweites Gesetz zur Änderung des Gesetzes gegen Wettbewerbsbeschränkungen, 1973 BGBl.I 917 (Ger.) 
Böhm's leading assistants, Ernst-Joachim Mestmäcker, succeeded to Böhm's intellectual leadership in competition law and became the first president of the Monopoly Commission. Many of the dominant figures in the next generation of competition law scholars have, in turn, been students of Mestmäcker. ${ }^{168}$

\section{The Story and Its Roles}

Ordoliberalism has thus played a central role in structuring the evolution of German thought and institutions relating to law, economics and economic policy. The foremost vehicle for ordoliberal influence in shaping thought in these areas has been the new language it generated. This language features both a new grammar and a significantly altered vocabulary. The grammar - i.e., the rules that structure the language - is based on the interplay of economic and legal ordering concepts. Economic analysis supplies the rules necessary for the market to function effectively and thus provides the standards for most economic policy decisions. Legal ordering concepts then serve to assure that the government acts in ways appropriate to translating this economic model into reality. In this language, economic policy decisions are dictated not by powerful institutions and interest groups, but by general principles chosen by the community and designed to integrate the market into society.

This language contains new concepts, and it has altered the meanings of existing ones. Concepts such as "economic constitution," "economic power," "performance competition," and "market conformity" were either ordoliberal neologisms or existing concepts to which the ordoliberals gave new roles and meanings. As with language change generally, however, once the words became widely accepted, the original sources of interpretational guidance were often forgotten, and thus the ordoliberal impact in this area is often overlooked. ${ }^{169}$

This new language helped to alter existing patterns of thought concerning law's relationship to the economy. "The return of the influence of liberal ideas in Germany was not due solely to the Freiburg School. Unquestionably, however, it played the essential role in detaching the Germans from the dirigistic and planist ideas of the period."170 Throughout the 1950s and into the 1960s the discourse of ordoliberalism channeled German economic and political thought. Ordoliberal authors were widely read, and scholars produced an entire body of works in that idiom. Ordoliberal doctrine provided a

168. For example, Ulrich Immenga is one of the three presidents of the Monopoly Commission since Mestmäcker, and Wernhard Möschel is the current law professor on the Commission.

169. See Bilger, supra n. 11, at 231-2.

170. Id. at 207. 
clear conceptual framework, and ended, albeit temporarily, the segregation of legal and economic thought.

For almost two decades, ordoliberal thought also played a predominant role in guiding economic policy decisions in Germany. ${ }^{171}$ Ludwig Erhard consciously applied its basic principles in the formulation and implementation of German economic policy. He vigorously and consistently pursued the primary ordoliberal goal of combatting inflation, and, as a result, Germany's monetary stability has been the hallmark of its economic policy for more than four decades. Germany's competition law - inspired and developed primarily by ordoliberals - has led European, if not world, developments in combatting restraints on competition. Internally, ordoliberal ideas play important roles throughout the process of economic policy making. For example, virtually all governmental departments dealing with the economy - and often other departments as well - have "principles sections (Grundsatzabteilungen)" in which close attention is paid to the ordoliberal demand that individual policy decisions be related to each other and to the general principles they attempt to implement.

The direct influence of ordoliberal ideas reached its apogee in the late 1950 s and early 1960 s when they represented something like orthodoxy among policymakers and thinkers in Germany, but around this time their role also began to change. As the central ideas of ordoliberalism were absorbed into the culture and language of economic policy making, people became less aware of the origin of these ideas. Moreover, Germany's economic successes and political stability had reduced the perceived urgency of some of the fundamental ordoliberal issues. ${ }^{172}$ In addition, leaders of the social market economy such as Müller-Armack began to talk about a second phase of the social market economy, in which there would be greater emphasis on the social uses of the wealth that had been created by the German miracle. ${ }^{173}$ In effect, the ordoliberal elements in the concept of the social market economy that had played a central role in the reconstruction of the German economy were gradually reduced in importance in favor of the "social" elements. ${ }^{174}$ The emphasis in "social market economy" shifted from "market" to "social."

171. See generally Schlecht, supra n. 57.

172. See, e.g., Oberender, "Der Einfluss ordnungstheoretischer Prinzipien Walter Euckens auf die deutsche Wirtschaftspolitik nach dem zweiten Weltkrieg: Eine ordnungspolitische Analyse," 40 ORDO 321 (1989).

173. According to Müller-Armack, this second phase of the social market economy would focus on improving "the quality of life," and he included here "education, personal asset formation, environmental quality and. . urban policy." Müller-Armack, Genealogie, supra n. 136, at 10.

174. On the various directions in social market economy thinking during this period, see Blum, supra n. 27, at 278-9. See also Heusgen, supra n. 141, at 286-315. 
This change also coincided with shifts in political power and in economic thought. In 1966 the long era of CDU government ended. A "Grand Coalition" between the social democrats and the CDU operated until 1969, when the social democrats finally won control of the federal government, which they maintained for more than a decade. In the German economics profession interest shifted to Anglo-American, particularly Keynesian, theories and to a new emphasis on fiscal and monetary policy to promote maximum employment and economic growth. In 1967, a change in the direction of economic policy was marked by the Statute on Stability and Growth (Stabilitäts- und Wachstumsgesetz) which led to what has been called a mixture of Eucken and Keynes. ${ }^{175}$

By the late 1970s, however, interest in ordoliberal ideas had revived, and the return of the CDU to political power in the 1980s helped translate this interest into a renewed influence of ordoliberal ideas on economic policy. ${ }^{176}$ Thus the story of ordoliberal influence in Germany has by no means ended - the ideas of Eucken and Böhm remain a significant force, not only through their influence on economic policy thought and traditions, but as a guide to current policymaking.

\section{Freiburg and Europe}

The influence of ordoliberal ideas also extended beyond Germany. In part, their influence rests on the success of the social market economy in Germany and on respect for the ideas perceived to be responsible for this success. In addition, however, ordoliberal ideas have penetrated the thought, institutions and practices of the European Community, and this has spread their influence throughout the member states of the Community.

Scholars have generally paid little attention to ordoliberalism's influence outside Germany. In the early postwar period, in particular, this lack of attention was tied to ordoliberalism's German origins. Although ordoliberal thought was antithetical to nazism, and although the ordoliberals themselves often were victims of the Nazi regime, they were still German in a world in which there was much resentment toward "things German." In recent years the disincentive to studying these ordoliberal influences has been the political dynamic of the process of European unification, which impedes recognition of national influences on this process. ${ }^{177}$ The identifica-

175. See Schlecht, supra n. 57, at 313-4.

176. One commentator has ascribed much of the responsibility for this renaissance to the Federal Economics Ministry. See Schlecht, id. at 318.

177. See generally Koopmans, "The Birth of European Law at the Crossroads of Legal Traditions," 39 Am. J. Comp. L. 493 (1991). Germans in Community institutions have also tended not to focus attention on their philosophical positions. 
tion of ideas or programs with particular member states is regarded as likely both to increase resistance to such ideas and to interfere with Europeanization, and this creates a powerful incentive to avoid such identification. As a result, I can do little more than sketch the outlines of ordoliberal influence outside of Germany. Although intellectual and political factors were intertwined in spreading and deepening the influence of ordoliberal ideas, it is useful to separate the two strands of the process for analytical purposes.

\section{A. Intellectual Reception}

Neo-liberals living outside Germany during the war prepared the way for the rapid spread of ordoliberal ideas in postwar Europe. The ideas spread principally along the networks established by Röpke, Hayek and others. Röpke had actively promoted his brand of ordoliberal thought from his base in Switzerland, and his extensive journalistic activities achieved a wide following on both the popular and intellectual levels in many areas of Europe. In particular, he had a coterie of friends and supporters in the media and in government in England, France and Italy. ${ }^{178}$ Beginning in the early 1930s, Friedrich von Hayek had been preaching his neo-liberal message from the London School of Economics. He had there become an important figure in the social sciences, ${ }^{179}$ publishing widely in English and helping to establish that institution as a major center for neo-liberal thought. These activities also facilitated the acceptance of ordoliberalism by highlighting the contrast between neo-liberal ideas and the ideas of the Nazi regime. In a sense, they helped "cleanse" these ideas of potential associations with the Nazi regime, fostering the perception that they represented a common European front against totalitarianism and the recent past.

During the immediate postwar period, Röpke and Hayek, in particular, continued to use their respective bases to influence European thought. For example, in 1947 Hayek gathered a group of leading economists and politicians from many European countries at a conference on Mont Pelerin, Switzerland. From this meeting developed the Mont Pelerin Society, which has been an influential force in maintaining neo-liberal and particularly Hayekian ideas. As soon as postwar conditions in Germany permitted them to travel, Eucken, Böhm and other ordoliberals joined this proselytizing activity, lecturing and participating in seminars throughout Europe and the United States. Walter Eucken died on a lecture tour in England in 1950.

By the early 1950s, German neo-liberal ideas were being discussed in academic (economic) circles in several European countries.

178. Bilger, supra n. 11, at 96-7.

179. See generally Leube, "Friedrich A. von Hayek zum 90. Geburtstag," 40 ORDO xxi (1989). 
In France, for example, numerous scholarly analyses of German neoliberalism were written by influential economists in the $1950 \mathrm{s.}{ }^{180}$ Raymond Barre, later to become a leading economics professor in France (and still later Prime Minister), wrote one of the earliest scholarly articles on ordoliberalism in $1952 .{ }^{181}$ In Italy, the economist Luigi Einaudi maintained an important neo-liberal school in Turin that had ties to Wilhelm Röpke. ${ }^{182}$ These economists' channels carried German neo-liberal ideas throughout Europe, often intermingling them with the neo-liberal ideas of the American Walter Lippman in the process. ${ }^{183}$

\section{B. Ordoliberals and European Unification}

The main vehicle for disseminating the ordoliberal version of neo-liberalism outside of Germany has been the process of European unification. Through their influence on thought and institutions in the European Communities, these ideas have acquired a degree of dispersion and a level of force that they are unlikely to have acquired in any other way. Unfortunately, this vehicle of influence has tended to conceal the sources of the ideas.

Ordoliberal ideas suffused the process of European unification at its earliest stages and its highest levels. Most of the leading German representatives in the founding of the European Communities were closely associated with ordoliberalism or at least shared an appreciation of it. Walter Hallstein, for example, was one of the founders of the European Communities and the first president of the European Commission. He had been a law professor in Germany and a friend of Heinrich Kronstein. He became associated with the ordoliberals during the 1940s, acquiring a high regard for the ideas of Walter Eucken. ${ }^{184}$ Many of his views on the role of law in shaping the future of

180. See, e.g., Bertrand, "La Notion d'Ordre Économique et ses Possibilités d'Utilisation," 31 Revue D'Histoire Économique et Sociale 152 (1953); Meynaud, "Pouvoir Politique et Pouvoir Économique," Revue Économique 925 (1958); Jacques Cros, Le Né-Liberalisme: Etude Positive et Critique (1951). Note that the discussion in France tended to focus more on the work of Wilhelm Röpke than on that of the Freiburg School. See Bilger, supra n. 11, at 6.

181. Barre, "L'Analyse économique au service de la Science et de la Politique Economique," 8 Critique 331 (1952)(a review essay on the English translation of Eucken's Grundlagen der Nationalökonomie). As Prime Minister in 1977, Barre was the impetus behind a significant strengthening of French competition law. See Hervé Dumez \& Alain Jeunemaitre, La Concurrence en Europe: De nouvelles règles du jeu pour les enterprises 76-7 (1991).

182. See, e.g.., Antonia D’Aroma, Luigi Einaudi: Memorie di Famiglia e di Lavoro 351 (1967).

183. For discussion of this intermingling in France, see Cros, supra n. 180, at 167222.

184. For a brief biographical sketch of Hallstein and his roles in the creation of the European Communities, see Loch, "Einleitung und biographische Skizze," in Walter Hallstein und die junge Generation 7-47 (Theo M. Loch ed. 1967). Hallstein's speeches and writings in relation to the Community are replete with ordoliberal con- 
European institutions clearly reflect ordoliberal ideas, and he actively propagated and pursued these ideas during the formative period of the European Community. Another key figure with strong ties to ordoliberalism was Hans von der Groeben, one of the two principal drafters of the so-called "Spaak Report," the document on which. the Rome treaty was based. ${ }^{185}$ Finally, Müller-Armack, the creator and a chief proponent of social market economy ideas, was as an offi-. cial of the German government himself responsible for influencing the development of European Community economic policy during its formative years. ${ }^{186}$

Although they supported the process, ordoliberals did not provide the primary political impetus for establishing a European common market. Credit here goes to leaders such as Jean Monnet and Robert Schuman of France and Paul-Henri Spaak of Belgium. ${ }^{187}$ Ordoliberal thought did, however, provide a comprehensive and theoretically grounded set of ideas that helped give legal and institutional form to general political goals. It supplied a framework for the process of European integration that has been highly influential among most Germans involved in European unification and has influenced other leaders as well.

Ordoliberal ideas were particularly well suited to the pursuit of European unification through creation of a common market. This task called for establishing a new community centered on the operation of a market economy - the central objective of ordoliberal thought. The community was to be based on a voluntary agreement, which could play a role similar to that played in ordoliberal thought by the concept of an economic constitution. ${ }^{188}$ Ordoliberal thought could for these reasons be seen as directly applicable to the problems of this new community, and the German representatives in the creation and early structuring of the European Community tended to see the process in this light. 189

cepts and references. See, e.g., Walter Hallstein, Europe in the Making 28 (1972) ("What the Community is integrating is the role of the state in establishing the framework within which economic activity takes place.")

185. See generally Hans-Jürgen Küsters, Die Gründung der Europäischen Wirtschaftsgemeinschaft 135-160 (1982).

186. For his own discussion of his roles in the development of Community thought and institutions, see Alfred Müller-Armack, Auf dem Weg nach Europa (1971).

187. See generally Jean Monnet, Memoirs (Richard Mayne trans. 1978).

188. The interpretation of the treaty as a "constitution" has channeled the evolution of the Community, and this interpretation undoubtedly owes much to ordoliberal thought. See, e.g., von der Groeben, "Der gemeinsame Markt als Kern und Motor der Europäischen Gemeinschaft," in Europa Ringt um seine Wirtschaftsverfassung (Festschrift für Karl-Heinz Narjes) 19, 30 (1984) and Zuleeg, "Die Wirtschaftsverfassung der Europäischen Gemeinschaften," in Wirtschaftspolitische und Gesellschaftspolitische Ordnungsprobleme der Europäischen Gemeinschaft 73 (Schriftenreihe des Arbeitskreises Europäische Integration e.V. 1978).

189. See, e.g., Mestmäcker, "Auf dem Weg zu einem Ordnungspolitik für Europa," in Eine Ordnungspolitik für Europa 9 (Festschrift für Hans von der Groeben 1987). 


\section{Community Competition Law}

Ordoliberal influence has been particularly direct and obvious in relation to competition law. Competition law provisions were included in the Rome Treaty under German pressure. 190 The Germans had just completed almost a decade of debates about competition, and had just passed Europe's first modern competition statute. ${ }^{191}$ As a result, they emerged as leaders in this area - as illustrated, for example, by the appointment of von der Groeben as the first Commissioner for Competition Policy of the European Commission. Thus, especially in the early years of European competition law, ordoliberal thought set the tone for thinking about competition law within the Communities.

The Rome Treaty reflects this influence. It contains two main competition law provisions: a prohibition of cartels (article 85) and of abuse of a market-dominating position (article 86). This structure closely tracked ordoliberal thought and the patterns established in the GWB, and bore little resemblance to anything found in other European competition laws at the time. ${ }^{192}$ Moreover, while the prohibition of cartel agreements had analogues in U.S. antitrust law, the concept of prohibiting abuse of a market-dominating position was an important new development closely associated with ordoliberal and German competition law thought, and very different from U.S. concepts. ${ }^{193}$

Ordoliberal thought has also played a major role in the development of Community competition law. A tradition has developed, for example, that the competition directorate be headed by a German, and this has cemented close ties between German and Community competition law. Moreover, this influence is often evident in the development of the law by the European Commission and the European Court of Justice, for concepts developed in German competition law frequently find their way into the competition law of the Community. Interpretation and application of the concept of abuse of a market-

190. See, e.g., Bayliss \& El-Agraa, "Competition and Industrial Policies with Emphasis on Competition Policy," in Economics of the European Community 137, 140-1 (A.M. El-Agraa ed. 3d ed. 1990).

191. "Without this battle [for the GWB] there probably never would have been the prohibition of cartels or the abuse supervision in the EC treaty." Schlecht, supra $n$. 57 , at 11.

192. This is not to deny the existence of language in several postwar statutes of other European countries that resembled language in articles 85 and 86 . Such language had functions, however, that were very different from those created by the Rome Treaty. For a brief description of postwar European competition law legislation, see Thorelli, “Antitrust in Europe: National Policies After 1945," 26 U. Chi. L. Rev. 222 (1959).

193. For discussion, see Gerber, supra n. 113, at 57. 
dominating position often reflects, for example, the influence of German legal developments. ${ }^{194}$

\section{Toward a European Competition Law Tradition}

The central role of Community competition law in Europe has led, in turn, to the diffusion of ordoliberal ideas to national legal systems. This has been particularly significant during the last decade, as member states have created national competition laws modelled on European Community and German law, or have altered existing laws to conform to those models. With Italy's enactment of a competition law in 1991, all member states now have competition laws, and they increasingly reflect the influence of Community competition law. ${ }^{195}$ Through this process of diffusion and increasing standardization, ordoliberal ideas have contributed to the formation of a "European" conception of competition law. In it, the law's role is to eliminate or reduce harm to the competitive process. Its substantive rules focus on eliminating excessive economic power from the market or, where this is not practicable, preventing the use of such power to distort competition. Its procedural mechanism seeks impartial application of the laws through an "expert" governmental body insulated as much as possible from political influence. ${ }^{196}$ This model and the tradition that has formed around it have played, and continue to play, a central role in the process of European integration. ${ }^{197}$

\section{E. Ordoliberalism and the Transformation of Europe?}

Outside the area of competition law, demonstrating and assessing ordoliberal influence on European development becomes more difficult. Nevertheless, ordoliberal ideas clearly have helped to shape a new way of thinking about law, the economy and the relationship between the two that has deeply influenced European institutions. For this reason the ordoliberal story provides valuable insights into the structures of thought and the dynamics of institutions.

\section{Ordoliberalism: The Guidance Function}

Although my primary aim in this paper has been to analyze ordoliberal ideas and their impact, the importance of these ideas demands at least brief reflection on their potential value as guides for

194. See, e.g., id. at 93-4.

195. See, e.g., Vincenzo Donativi, Introduzione della disciplina Antitrust nel sistema legislativo italiano (1990) and Donald, "Comments on the Italian Antitrust Law of October 10, 1990," 26 Intl. Law 201 (1992).

196. There are important differences, however, among European jurisdictions regarding the "appropriate" degree of political insulation.

197. See generally Gerber, "The Transformation of European Community Competition Law?," 35 Harv. Int'l L. J. 97 (1994). 
current decision-making. At least for some purposes, ordoliberalism continues to merit attention, particularly in the post-socialist world and in the context of European integration.

\section{A. An Ordoliberal Perspective in the 1990s?}

From the perspective of the 1990s, the ordoliberal program appears outdated in many respects. In part, this is a function of changed circumstances. The ordoliberals were responding to an extraordinary situation, and it is tempting to dismiss their ideas as necessarily linked to that situation. Except in the special circumstances of the post-socialist world, few new societies are being created from the ruins of destroyed ones; consequently, the reconstructive perspective of the ordoliberals seems vaguely alien to most of us. More important, however, is that we no longer have confidence in some of the assumptions on which the ordoliberal program was based, and thus it does not always comport easily with contemporary thought. ${ }^{198}$ The ordoliberal emphasis on the interdependence between economic structures and human values is, for example, reminiscent of a type of discourse that (at least in the United States) has been relegated to political speeches and utopian pronouncements. It fails to resonate with most levels of current thought, where economic issues such as efficiency and wealth creation are ever more strictly divorced from non-economic issues such as political freedom.

The ordoliberal vision of economic reality also seems increasingly outdated. Few markets of importance resemble the image of powerless price-takers that pervades ordoliberal literature. Competition in important contemporary markets typically involves small numbers of suppliers and strategies for success far different from those anticipated in the complete competition model. The ordoliberal focus on the potential harms of economic power also seems less important, because in most important markets the growth of international competition tends to diminish such power.

If we turn to assumptions about the political system, similar doubts about the relevance of ordoliberal thought arise. For example, few today share the ordoliberal confidence in the capacity of legislatures to create clear and dependable laws of any sort, much less a constitutional framework for the economy. The experience of recent decades suggests that legislatures have great difficulty avoiding interventionist regulation at the behest of one or another political or economic interest group. Finally, ordoliberal assumptions about the

198. For an insightful presentation of the potential value of ordoliberal thinking in responding to environmental problems, see Fikentscher, "Free Trade and Protection of the Environment as an Integrated Value System: Outline of an Environment-Conscious Social Market Economy - A Lawyer's View," 3 Juridisk Tidskrift vid Stockholms Universitet 205 (1992). 
legal system are often suspect. Particularly in the legal realism-dominated legal world of the United States, many reject the proposition that articulated legal norms can generally be relied on as effective guidelines for conduct.

\section{B. Constitutionalizing the Economy}

Although certain elements of the ordoliberal program may have lost their appeal as guides for current thought, other perspectives and insights from the ordoliberals' constitutionalizing agenda continue to merit attention. The ordoliberals sought a path to dependable economic strength that was compatible with maximum personal freedom and improved social conditions, and this objective remains central to social and political thought, at least in Europe and the United States. According to the ordoliberals, two main obstacles blocked the path to these objectives, and both remain firmly in place. One was inadequate understanding of systemic relationships within the economy itself and between the economy and the community. The other was the lack of an effective conceptual and institutional framework for government activity relating to the economy - the problem of "muddled interventionism." The ordoliberals sought to eliminate both through the creation and implementation of an economic constitution.

The ordoliberals believed that effective implementation of such a program would require a broadening and deepening of economic knowledge throughout society. For them, an economic constitution was a social choice; it could only serve to integrate society around the market where there was a widely shared understanding of the nature and function of a market economy, including recognition of a high level of interdependence between the economy and the legal system. A market economy could function best where government maintained the conditions of competition and avoided interference in market outcomes (unless they eliminated competition), and government could best protect personal and political freedoms where the market provided a prosperous and stable economic framework for the community that was widely accessible to its members and generally perceived as fair. In many places today these relationships are only weakly perceived, if at all: the ordoliberal perspective offers, at the very least, a stimulus to focusing on them.

But the ordoliberals also provided an activist program for the protection of these relationships - "activist" in the sense that it tied analytical insights into problems to prescriptions for institutional responses. Here the concept of an economic constitution was central, because if a constitutional choice regarding the economy acquired the same status as a political constitution, adherence to its dictates would be mandated. Any governmental action that does not conform 
to constitutional economic principles should be overturned by the courts, they argued, just as if it had violated the political constitution.

This perspective addresses the problem of "muddled interventionism" that remains so pervasive throughout the world. ${ }^{199}$ Most thinking about the role of law in the economy is locked in discourse about "how much intervention," and for the ordoliberals this conceptualization was the heart of the problem. Where there was no mechanism for relating decisions affecting the economy either to each other or to general authoritative principles, they said, there was no way of predicting the impact of government action. The effects of any particular act were likely to be counteracted, at least in part, by other governmental actions; as a result, government would merely "interfere" with the economy. Without an economic constitution to both coordinate and constrain governmental actions, the only issues remaining would be "how much intervention" and "for whose benefit."

The concept of "constitutionalizing" the economy remains an intriguing insight. A constitutional framework for controlling the relationships between government and the economy has not been tried or seriously considered outside of Germany and, to a limited extent, the special circumstances of the European Community. In both cases it has been surprisingly successful, and this alone should induce further consideration of its potential for adaptation to other situations.

\section{Competition Law}

Ordoliberal thought also provides insights into current problems in the area of competition law. In many legal systems, for example, there is uncertainty about the value of antitrust regimes. The question is posed: To what extent do the benefits of these regimes justify the resources spent in enforcement or diverted in compliance? Some claim that the market will eventually undermine most, if not all, positions of economic power, and thus there is no need to involve government in the undertaking. Governmental involvement, they argue, may actually create more problems than it solves, because it necessarily interferes with market processes. In addition, antitrust law puts power in the hands of government officials who may use such power for ends unrelated to the protection of competition. Finally, it is sometimes suggested that even if antitrust laws had an important role to play in the past, the increasing internationalization of the

199. "The traditional way of viewing economic policy assumes a thesis-antithesis process and arrives at three types: there are the models of complete liberalism and of the totally-planned economy, and the practice of most states lies somewhere between them. The decisive importance of the Freiburg School was to break this tripartite scheme." Fikentscher, supra n. 2, at 42. 
economy enhances competitive forces and thus diminishes the need for antitrust law. ${ }^{200}$

From an ordoliberal perspective, these concerns do not undermine the importance of competition law. First, history had convinced the ordoliberals that economic power positions were not easily weakened. Focusing on the process of industrialization in Europe, and on the Weimar period in particular, they were convinced that such positions tended to perpetuate themselves and even to strengthen over time. Second, the idea that competition law "interferes" with the market misses the point, because that criticism takes a short-term rather than a long-term perspective. From the latter perspective, measures that maintain the conditions of competition can hardly be said to interfere with competition. Third, criticism of the discretionary power placed in the hands of administrators does not apply to the ordoliberal conception of competition law, because a cardinal principle of their framework is that competition law should not place any significant degree of discretionary power in the hands of administrators - rather they are authorized only to implement the fundamental principles of the economic constitution. Finally, as to the impact of internationalization on competitive structures, an ordoliberal response is likely to focus on the issue of whether such processes actually reduce the capacity of firms to coerce the behavior of other firms. Where they do, this would automatically reduce the need for enforcement action, and the result would be welcome.

Claims of competition law's ineffectiveness also play a role in such criticisms. Some argue that competition laws have not curtailed rapid increases in the concentration of industry, as merger waves have swept over economies with significant antitrust regimes (e.g., the United States and Germany) with little noticeable restraint from competition laws. Moreover, economic power positions seem to be as significant a problem in such countries as in other countries with weaker antitrust regimes. An ordoliberal perspective suggests two responses. One is that there is little point in viewing the issue in global and purely economic terms. In the ordoliberal view, competition law seeks to protect economic freedom, and the fact that there continue to be power positions does not necessarily mean that competition law has not contributed to protecting those freedoms. The other is that competition law cannot be fully effective unless it functions as part of a comprehensive legal framework, receiving support from other policies designed to achieve the same objectives. Therefore, since competition laws currently tend to operate as discrete areas of law with poorly-defined relationships to the rest of the legal system, they cannot be as effective as they otherwise might be.

200. The literature here is vast. See, e.g., Adams \& Brock, "The New Learning" and the Euthanasia of Antitrust," 74 Cal. L. Rev. 1515 (1986). 


\section{The Post-Socialist World}

The potential value of ordoliberal ideas as guides to current decision making is particularly striking in the post-socialist world. The ordoliberals played an important part in paving the road that the formerly socialist countries are now seeking to follow. These countries need to understand how the road was constructed - the ideas that fashioned it, the circumstances to which the road-builders were responding, and the factors that led to its success - if they are to make informed decisions as to whether they should extend that road, how to adapt it to their own conditions and how to repair damage to it.

The circumstances that post-socialist countries face today resemble in many ways the conditions faced by German neo-liberals following the end of the Second World War. ${ }^{201}$ They are emerging from years of totalitarian rule into a highly unstable situation characterized by economic and political disorder and weakness. Moreover, the existing political and economic systems have collapsed, leaving a desperate need for a new political and economic framework. As in postwar Germany, these new regimes need rapid economic development merely in order to survive, and they generally accept the proposition that the market is necessary to achieve such development. Yet their populations have been accustomed to viewing the market as an enemy of social cohesion and a source of unfairness and exploitation, and thus there is much suspicion and fear of market processes.

The ordoliberal program addresses the need in these countries to find a path out of confusion and uncertainty. ${ }^{202}$ It first provides a conceptual framework that emphasizes the systemic relationships within a market society. This is particularly important where people cannot be expected to recognize the full range of implications of a market economy. It then demonstrates how the market can serve as the basis for a democratic and humane society. For entire communities that have been taught to view the market as an enemy of community, this set of insights is necessary to generate confidence that the market not only can create wealth, but can do so in a fashion that comports with deep-seated values of community and equity. Ordoliberalism in this way provides an important bridge from the radical communitarianism of socialist imprint to a market-oriented future. The ordoliberal concept of an economic constitution offers a means of implementing these insights. In communities in which laws have been understood as the discretionary will of a dominant party, it is critical to establish the notion that laws can be an "archimedes

201. See generally Gerber, "Integration, Disintegration and the Protection of Competition: Of Images, Stories and Myths," 68 Chi-Kent L. Rev. 229 (1993).

202. See, e.g., International Monetary Fund et al., 2 A Study of the Soviet Economy 295-301 (1991) and Langenfeld \& Blitzer, "Is Competition Policy the Last Thing Central and Eastern Europe Need?," 6 Am. Univ. J. Intl. L. \& Pol. 347 (1991). 
point" of stability and dependability rather than a tool of power. An economic constitution provides this dependability through a constitutionally-anchored framework of basic principles that are to control individual laws.

Finally, the post-socialist countries need to integrate their communities around a set of new ideas, and here again the ordoliberal program is specifically designed to foster such societal integration. The idea that the community must make a fundamental choice regarding an economic constitution that will then govern the actions of government with respect to the economy is critical in this regard, as is the ordoliberal insistence on the objectivity and dependability of the laws affecting economic conduct. The ordoliberals foresaw that the market could serve as the basis for societal integration only where all groups within the society perceived that it would operate fairly and not be distorted in favor of particular groups.

While the success of the social market economy in Germany urges the potential value of ordoliberalism as a guide for decisions in the post-socialist world, there are also important differences between that world and post-war Germany. The ordoliberals sought to resurrect a market economy in a situation where the values, attitudes and habits of such an economy had been well-developed and had been suffocated for the relatively short period of roughly one decade. Moreover, the political ideas of liberalism had deep roots in a large and well-educated middle class whose basic moral and intellectual frameworks were still intact. These conditions are seldom, if ever, met in the post-socialist world. A market economy is not part of the experience of the current communities in any of these states. Entrepreneurial habits and values are poorly established, if at all. The task of establishing a functioning market economy in these countries is thus significantly more difficult than it was in post-war Germany. Similarly, the political and legal prerequisites for a market regime have few, if any, roots in most of the post-socialist world. The tradition of liberal constitutionalism from which the ordoliberals drew many of their ideas and much of their support is, at best (e.g., in Hungary and Czechoslovakia) a memory in the minds of a few, and the need to introduce and inculcate these values takes on a particular poignancy.

Despite these differences in the circumstances in which they must operate, however, the ordoliberal program does address central needs of the post-socialist world. It was fashioned with the same problems in mind as those now faced there and sought many of the same ends now sought by leaders in these countries. 


\section{E. European and German Integration}

While Germany and the European Community do not face the need for radical reconstruction faced by the post-socialist countries, each must integrate a political community around a market economy, and in this context too ordoliberal thought offers useful insights. In Germany, the population of the former German Democratic Republic must be quickly integrated into the economy and society of Western Germany, ${ }^{203}$ while the European Community must rapidly achieve further economic, social and political integration of the twelve current member states and chart a course for integrating other states seeking membership.

In both Germany and the European Community, ordoliberal conceptions of the relationship between government and the economic system have played important roles in achieving current levels of prosperity and integration, as has a competition law regime structured along ordoliberal lines. In both, however, the capacity of law, in general, and competition law, in particular, to continue to play that role is being challenged. In Germany, there is a growing belief that Community law will take over many of the functions of domestic competition law and that there is, therefore, little point in expending resources on the latter. In Brussels, however, the autonomy of competition law has become highly controversial. Some important members states, particularly France, are urging a reduction in the autonomy of competition law in favor of a greater role for "industrial policy" considerations. ${ }^{204}$ From an ordoliberal perspective, failure to maintain the constitutional integrity of economic regulation, and particularly competition law, necessarily threatens both integration processes.

\section{F. The U.S. Antitrust Malaise}

Finally, ordoliberal ideas may also have potential value with respect to the current malaise in United States antitrust law. Doubts about the purposes, roles and effectiveness of antitrust law have led to a search for an improved framework for combatting distortion of the competitive process in the United States, but many doubt that such a framework has been found. In addition to the general issues concerning the importance of antitrust law discussed above, ${ }^{205}$ there has been dissatisfaction in the United States with the substantive content as well as the procedures of antitrust law.

203. See generally Horn, "The Lawful German Revolution: Privatization and Market Economy in a Re-Unified Germany," 39 Am. J. Comp. L. 725 (1991).

204. See, e.g., Johnson, "De Havilland Flak for Brittan," The Daily Telegraph, October 7, 1991, at 21.

205. See supra, text accompanying n. 200. 
The last three decades have been marked by the recognition that the conceptual framework of antitrust law has not provided sufficient reliability and consistency of application. Robert Bork's highly influential Antitrust Paradox was premised on the need for a substantive framework that provided more certainty of application than had been generated by decades of case law. ${ }^{206} \mathrm{He}$ concluded, and his argument has found much support, that price theory and the concept of allocative efficiency provided the best remedy for this situation.

Ordoliberal thought suggests a different means of achieving such dependability and conceptual integrity. For ordoliberals, as for Bork, economic thought has to play an important role, but the ordoliberals focused on the need to protect the conditions of competition rather than on competition's short-term results. Their program promises the sought-after legal dependability, but it does so by focusing on the protection of economic freedom and on the market's role as an integrative factor in the community rather than as merely a creator of aggregate wealth.

For the ordoliberals, economic power was the problem of competition law. They focused on the analysis of such power and constructed their entire system to combat it. The United States antitrust tradition, on the other hand, has tended to conceptualize economic power in narrow and static terms derived from microeconomic theory. The ordoliberals' careful, penetrating and comprehensive analysis of the roles of economic power in the economy may, therefore, be of value in the search for a more effective U.S. antitrust policy.

The ordoliberal program also suggests solutions to some of the procedural problems of U.S. antitrust law. Criticisms of U.S. antitrust law often focus on the unwieldiness and cost of its procedures, which are often seen as impairing its effectiveness. ${ }^{207}$ Where enforcement of the laws is primarily the responsibility of private plaintiffs and where civil suits tend to be very costly, financial and business strategy factors play an inordinately important role in the enforcement mechanism. Walter Eucken and his colleagues did not anticipate this particular problem of U.S. antitrust law, but their experience during the Weimar period led them to emphasize the need to protect the enforcement process from such distortions. Where firms seeking to avoid the constraints of competition law could use their financial resources to influence the enforcement process, or where firms with fewer resources were at a disadvantage in relation to that process, competition law could not accomplish its objectives. This insight applies to U.S. antitrust law, where enforcement procedures

206. Robert Bork, The Antitrust Paradox: A Policy At War With Itself (1978).

207. See generally, Natl. Commn. for the Review of Antitrust Laws and Procedures, Report to the President and Attorney General 11-114 (1979). 
have evolved with little attention to the need to shield those processes from distorting influences, whether political or financial.

At an even more fundamental level, an ordoliberal perspective suggests that the inadequacies of U.S. antitrust law are associated with the failure to place antitrust law in the context of a comprehensive "constitutional" scheme for the protection of competition. It may be, as Walter Eucken warned, that competition law cannot function adequately by itself and that it needs to be imbedded in a broader framework of law and policy. Thus, he might suggest, improvement in the effectiveness of antitrust law in the United States might well depend on a rethinking of its relationship to other policies affecting the economy.

\section{Concluding Perspectives}

Ordoliberal thought has played an important role in shaping German and European thought and institutions during the last half century. Without an appreciation of its concepts and architecture, much of the discourse about economic policy in Germany - and to some extent in the European Community - is likely to be misunderstood.

The ordoliberals redefined the tradition of economic liberalism and in so doing helped to resuscitate it. 208 All but universally disparaged in Europe for decades, liberalism resurfaced under their aegis. In place of the nineteenth century laissez-faire version of liberalism, however, the ordoliberals articulated a new version in which law was a necessary companion of the market, transforming it from a source of social divisiveness into a tool for social integration. In this new version of liberalism, the market was necessary, but not sufficient. The economy needed to be imbedded in a constitutional-legal framework that would both protect it and help integrate society around it.

Ordoliberal thought added new legal and social dimensions to the liberal tradition. The legal dimension required law to protect the market from the destructive influences of political and economic power. Law was necessary to establish and maintain a constructive relationship between economy and society. The market could not to be allowed, therefore, to function as an independent entity over which there was no control. The social dimension attached new values to the wealth-producing capacities of the market. Ordoliberalism (particularly within the context of social market economy doctrine) demanded that the market be more than an autonomous mechanism supplying individuals with economic benefits according to either

208. "What separates us from the economic liberalism of the 19 th century is that we have learned to distinguish between laissez-faire and competition, that we very definintely want to shape an "Ordnung" and that we think in terms of economic constitutions." Miksch, Wettbewerb als Aufgabe, supra n. 116, at 220. 
their abilities or their social or political power. It was conceived as part of a process of social integration. Competition and the market were no longer to be viewed as the enemies of the weaker members of society, but as their allies.

Underlying this new version of liberalism was an even more fundamental change in perceptions of the relationships between the market and society. The neo-liberals brought a new ethos of humanism to the liberal tradition. As a French observer wrote in 1965, "In these [ordoliberal] works we find an apologia for measure in all things, for equilibrium, for harmony, for the classical humanism which seemed to characterize Germany in the eyes of the French from the beginning of the nineteenth century to $1870 .{ }^{209}$

The keystone of the ordoliberal program is the perception that the legal and economic components of community are systemically interrelated. The ordoliberals emphasized that the domains of law and economy were inseparably intertwined and that, therefore, an effective economic policy must reflect that interpenetration. They believed that the systemic nature of this relationship required economic and legal thought to operate symbiotically, each providing insights as well as constraints useful to the other. This perspective was instrumental in structuring the ordoliberal program and securing its success, and it continues to provide valuable insights into the challenges of shaping a society in which the market creates wealth in a way that serves the interests of all members of the community.

Yet it is a perspective that is exceptionally difficult to maintain and to operationalize. ${ }^{210}$ It demands that economists, lawyers and administrators effectively utilize a shared conceptual framework, and it presupposes structures of communication and interaction that allow information to flow freely among these three groups. The almost total ignorance of ordoliberal thought among non-economists outside of Germany testifies to the difficulty of fulfilling these requirements, but the potential value of the benefits to be gained may well justify the effort.

Aided by favorable political circumstances, the ideas of the ordoliberals changed the course of European history. Yet their very success in structuring thought has combined with the particular circumstances of the post-war period to obscure their importance for many current observers who are unaware of how easily a different path might have been taken. Developments in the post-socialist world should remind us of the monumental importance of that change of course and of the potential power of those ideas.

209. Bilger, supra n. 11, at 279.

210. The difficulties of creating and maintaining such a cross-disciplinary interpretative community are discussed with insight and imagination in James B. White, Justice as Translation (1991). 